\title{
14. ANATOMY AND EVOLUTION OF THE INNER PERIMETER RIDGE (SITES 874 AND 877) OF A CAMPANIAN-MAASTRICHTIAN ATOLL-LIKE STRUCTURE (WODEJEBATO GUYOT, MARSHALL ISLANDS) ${ }^{1}$
}

\author{
Gilbert F. Camoin, ${ }^{2}$ Annie Arnaud Vanneau, ${ }^{3}$ Douglas D. Bergersen, ${ }^{4}$ Michel Colonna, ${ }^{5}$ Philippe Ebren, ${ }^{2}$ \\ Paul Enos, ${ }^{6}$ and Jim G. Ogg ${ }^{7}$
}

\begin{abstract}
The inner perimeter ridge of Wodejebato Guyot (Marshall Islands) is the subject of a detailed sedimentologic, seismic, and geochemical study. The deposition of the shallow-water carbonate sequence, 177.7-190.2 m thick, is related to a two-stage transgression leading to the development of fringing sand shoal facies overlain by early cemented rudist-coralgal "reef" units that constituted barrier-like features. Wodejebato Guyot exhibited, at least temporarily, an atoll-like morphology. The irregularities of the upper surface of platform carbonates, the occurrence of a trough separating the inner perimeter ridge from the outer one, and the formation of deep solution cavities in platform carbonates suggest karstification processes before the final drowning of the carbonate platform during Maastrichtian time. Drowning events were probably related to the combination of a rapid sea-level rise and climatic changes that characterize Maastrichtian time. Following the demise of the carbonate platform, subsidence possibly combined with eustatic sea-level changes carried rapidly the platform carbonates in a basinal setting below the aragonite saturation depth, resulting in dissolution of aragonite and subsequent in place precipitation of calcite cements possibly throughout the Cenozoic. Post-drowning sediments correspond to a phosphate-manganese crust that formed from the late Paleocene to the middle Eocene.
\end{abstract}

\section{INTRODUCTION}

Wodejebato Guyot $\left(12.0^{\circ} \mathrm{N}, 164.9^{\circ} \mathrm{E}\right.$; formerly Sylvania Guyot) is located approximately $74 \mathrm{~km}$ northwest of Pikinni Atoll in the northernmost part of the Ralik Chain in the Marshall Islands (see site map preceding title page). A volcanic ridge $20 \mathrm{~km}$ long and about $1500 \mathrm{~m}$ deep connects the two edifices. The summit of Wodejebato Guyot is about $43 \mathrm{~km}$ long and increases in width from less than $12 \mathrm{~km}$ in the southeast to more than $25 \mathrm{~km}$ in the northwest. Four lobes project from the edifice and, along with the volcanic spur attaching Wodejebato Guyot to Pikinni Atoll, give the guyot a distinct "starfish" appearance. The flanks of the guyot may be divided into a steep upper slope $\left(20^{\circ}-\right.$ $24^{\circ}$ ) and a more gently inclined lower slope (about $7^{\circ}$ ); the transition depth between these two zones is around $2500 \mathrm{~m}$. Sidescan images and seismic profiles collected during a pair of site survey cruises (Moana Wave cruises MW8805 and MW9009) show that two perimeter ridges lie along the shelves formed by the northern and northeastern flank ridge, and along the ridge extending southeast towards Pikinni Atoll (Bergersen, 1993). These perimeter ridges broaden across areas where the shelf margin widens (e.g., adjacent to the flank ridges).

The first observations on Wodejebato Guyot come from the late 1940s Operation Crossroads (Emery et al.,1954). Early dredges on this guyot recovered only basaltic rocks and tuff breccias (Hamilton and Rex, 1959; Duennebier and Petersen, 1982). Initial interpretations of the subsurface of Wodejebato were based on a limited number of

${ }^{1}$ Haggerty, J.A., Premoli Silva, 1., Rack, F, and McNutt, M.K. (Eds.), 1995. Proc. $O D P$, Sci. Results, 144: College Station, TX (Ocean Drilling Program).

${ }^{2}$ Centre de Sédimentologie et Paléontologie, U.R.A. 1208 du CNRS, Université de Provence, 3 place Victor Hugo, F-13331 Marseille Cedex 3, France.

${ }^{3}$ Institut Dolomieu, Université J. Fourier, Rue M. Gignoux, F-38031 Grenoble cedex. France.

${ }^{4}$ University of Sydney, Department of Geology, New South Wales, 2006 Australia.

${ }^{5}$ Département de Géochimie du B.R.G.M., GCH/TIE, B.P. 6009,45060 Orléans cedex 2. France.

${ }^{6}$ The University of Kansas, Department of Geology, 120 Lindley Hall, Lawrence. KS $66045-4974$, U.S.A.

${ }^{7}$ Purdue University, Department of Earth and Atmospheric Sciences, West Lafayette. IN 47907 , U.S.A analog single-channel seismic lines crossing the summit (Schlanger et al., 1987). During a 1988 Moana Wave cruise (MW8805) much of the site survey work on Wodejebato Guyot was performed (see Bergersen, 1993), and four more dredges attempted across the guyot recovered basalt, basalt breccia, basalt conglomerate, and limestone. From the study of these limestone samples, it was assumed that there were two distinct sequences of shallow-water carbonate accumulation, which were Albian and Campanian-Maastrichtian in age (Lincoln, 1990; Lincoln et al., 1993).

During Leg 144, two holes were drilled at Site 874 (Holes 874A and 874B) and one hole at Site 877 (Hole 877A) on the inner perimeter ridge of northeastern Wodejebato Guyot. Site 874 was located on the seaward summit of this ridge and Site 877 was in a slightly more inward position, $0.7 \mathrm{~km}$ northeast of Site 874 (Figs. 1-2).

The major objective of this paper is to reconstruct the depositional history of the shallow-water carbonate sequence that documents the submergence of a volcanic island followed by the development and the demise of a Campanian-Maastrichtian carbonate platform or atoll. Data used in this study include seismic, logging, sedimentologic, and geochemical methods.

\section{METHODS}

Geomorphic and stratal pattern interpretations are based on sidescan images, swath bathymetry, $3.5 \mathrm{kHz}$ and $12 \mathrm{kHz}$ echo sounder profiles and single and 6-channel digital seismics. During Leg 144, seismic data were recorded digitally on tape using a Masscomp 561 super minicomputer and also were displayed in real time in analog format on Raytheon electrostatic recorders using a variety of filter settings and scales.

In Hole 874B, suites of geophysical (two passes), geochemical, and Formation MicroScanner (FMS) (two passes) downhole logs were obtained from approximately $164 \mathrm{mbsf}$ (clay weathering profiles developed on basalt substrate) to $30 \mathrm{mbsf}$ (base of drill pipe). The geochemical logging record was extended to the sediment surface by measuring the neutron activation of various elements through the iron drill pipe. 


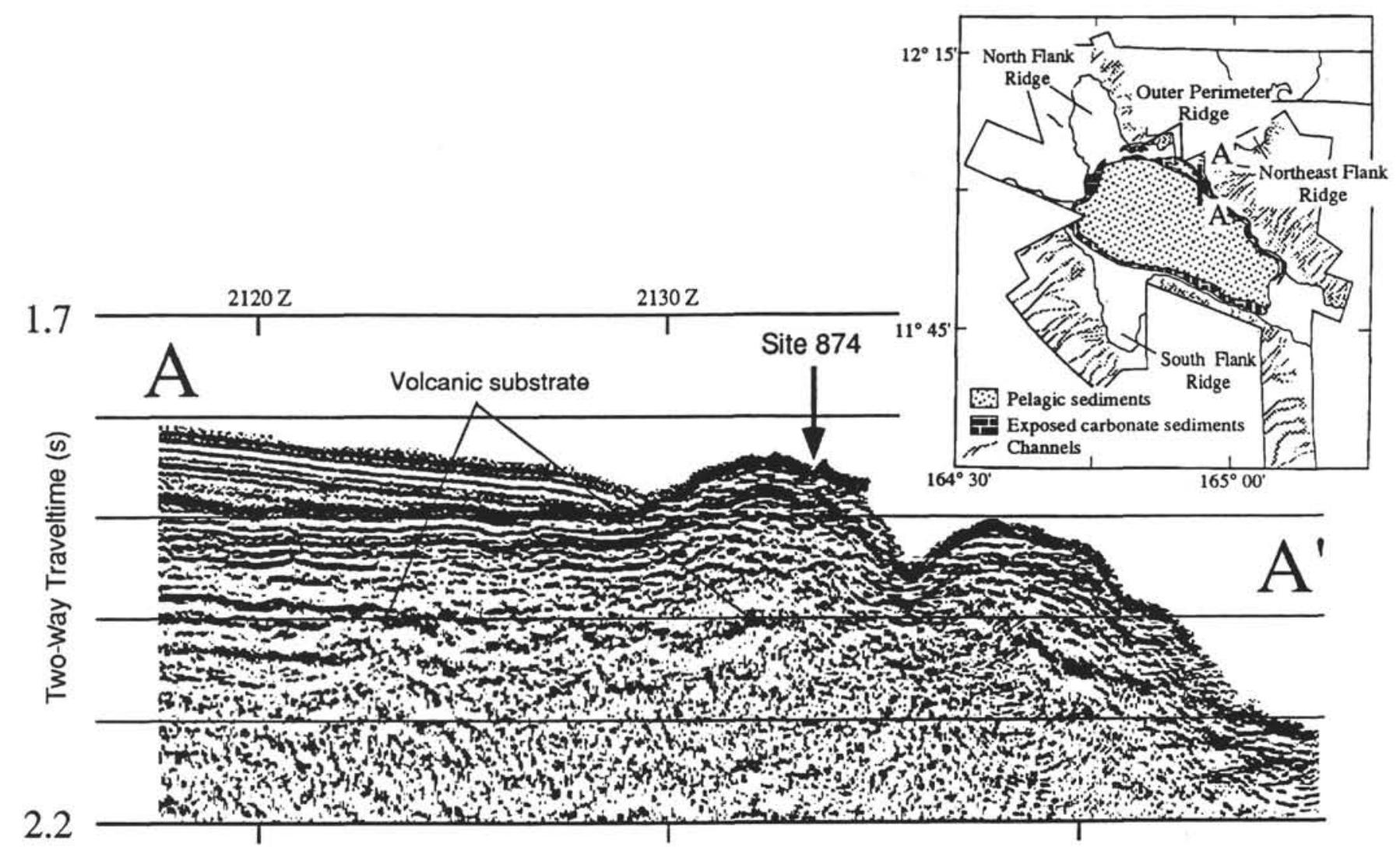

Figure 1. A portion of the migrated six-channel seismic profile. This line crosses the ridges obliquely. The strong reflector underlying the ridges marks the base of the carbonate sediments.

The logs were used for interpreting the sedimentary succession and possible discontinuities in accumulation within the carbonate platform. Core recovery within platform carbonates averaged only $10 \%$ in Hole $874 \mathrm{~B}$ and $13.3 \%$ in Hole $877 \mathrm{~A}$. In particular, the high-resolution micro-resistivity borehole-wall imagery from the FMS tool is excellent for determining the thickness and vertical succession of lithologies displaying similar "resistivity textures," which can be related to carbonate facies. However, interpretations of sedimentological features from FMS images have varying degrees of reliability (Bourke et al., 1989; Harker et al., 1990). Stratigraphic contacts, bedding thicknesses and dips, slumps, crossbedding, fractures, and rock textures, such as conglomerates, can generally be recognized on the FMS imagery. Other downhole logs, such as natural gamma ray, resistivity, porosity, and geochemical logs, were used for calibration of general compositional and textural trends. However, standard wireline logs do not provide the resolution of the FMS. Therefore, interpretation of finescale compositional contrasts, diagenetic variations, and other details noted on the images requires calibration with core data.

The geochemical records from the induced-gamma spectrum tool (GST) were converted by BRG-Lamont to relative elemental contributions: $\mathrm{Fe}$ (assuming an equal contribution by magnetite and hematite), $\mathrm{Ca}, \mathrm{Cl}, \mathrm{Si}, \mathrm{Su}, \mathrm{Ga}, \mathrm{Ti}$, and $\mathrm{H}$ (the last two elements were computed during processing) with corrections for hole diameter as recorded by calipers on the density tool (CALI on the HLDT) and on the FMS string $(\mathrm{C} 1$ and $\mathrm{C} 2$ ).

We used the Ca-abundance $\log$ at Site 874 to examine the relative change in calcium-carbonate weight-percent in the borehole outside of the drill pipe. These values were scaled to be compatible with the resistivity measurements and serve as a proxy to identify porosity trends.

Thin sections were prepared from cored samples and studied using petrographic microscopes coupled with cathodoluminescence. Scan- ning electron microscopy and electron microprobe (WDS) were also used. In order to obtain correlations between sites and general environmental gradients, we used correspondence analysis (CA) and then cluster analysis. First, we distinguished 13 grain types (variables) in thin sections (observations). Those grain types were red algae, green algae, benthic and planktonic foraminifers, corals, rudists and other bivalves, gastropods, ostracodes, echinoderms, lithoclasts, peloids, and unidentifiable bioclasts. To keep only significant biologic components, planktonic foraminifers, lithoclasts, peloids and unidentifiable bioclasts were excluded and the remaining component values recalculated to $100 \%$. The data were introduced into the correspondence analysis program as logarithmic values $\left[y=\log _{10}(x+1)\right]$ to avoid stretched point cloud. From coordinates of observations obtained with the $\mathrm{CA}$, cluster analysis classifies thin sections into groups interpreted as paleoenvironmental sets.

Carbonates were sampled for geochemical analyses using a miniature lath fitted with a 0.6 -mm-diameter dental drill. The drill was guided for geochemical subsamples during observation through a binocular microscope. Stable isotope analyses (carbon and oxygen) on samples of carbonates were performed at the Département de Géochimie du B.R.G.M. (Orléans, France), using FINNEGAN MAT 262 mass spectrometers. Reproducibility is $0.07 \%$ for $\delta^{18} \mathrm{O}$ and $0.05 \%$ for $\delta^{13} \mathrm{C}$. The $\delta^{18} \mathrm{O}$ and $\delta^{13} \mathrm{C}$ isotopic compositions are expressed as:

$$
\delta^{18} \mathrm{O}=\left[\left({ }^{18} \mathrm{O} /{ }^{16} \mathrm{O}\right) \text { sample } /\left({ }^{18} \mathrm{O} /{ }^{16} \mathrm{O} \text { standard }{ }^{-1}\right)\right] 10^{3}
$$

and

$$
\delta^{13} \mathrm{C}=\left[\left({ }^{13} \mathrm{C} /{ }^{12} \mathrm{C}\right) \text { sample } /\left({ }^{13} \mathrm{C} /{ }^{12} \mathrm{C} \text { standard }{ }^{-1}\right)\right] 10^{3} .
$$

The results are reported in the conventional delta notation (in per mil), relative to the Chicago PDB isotopic standard. 

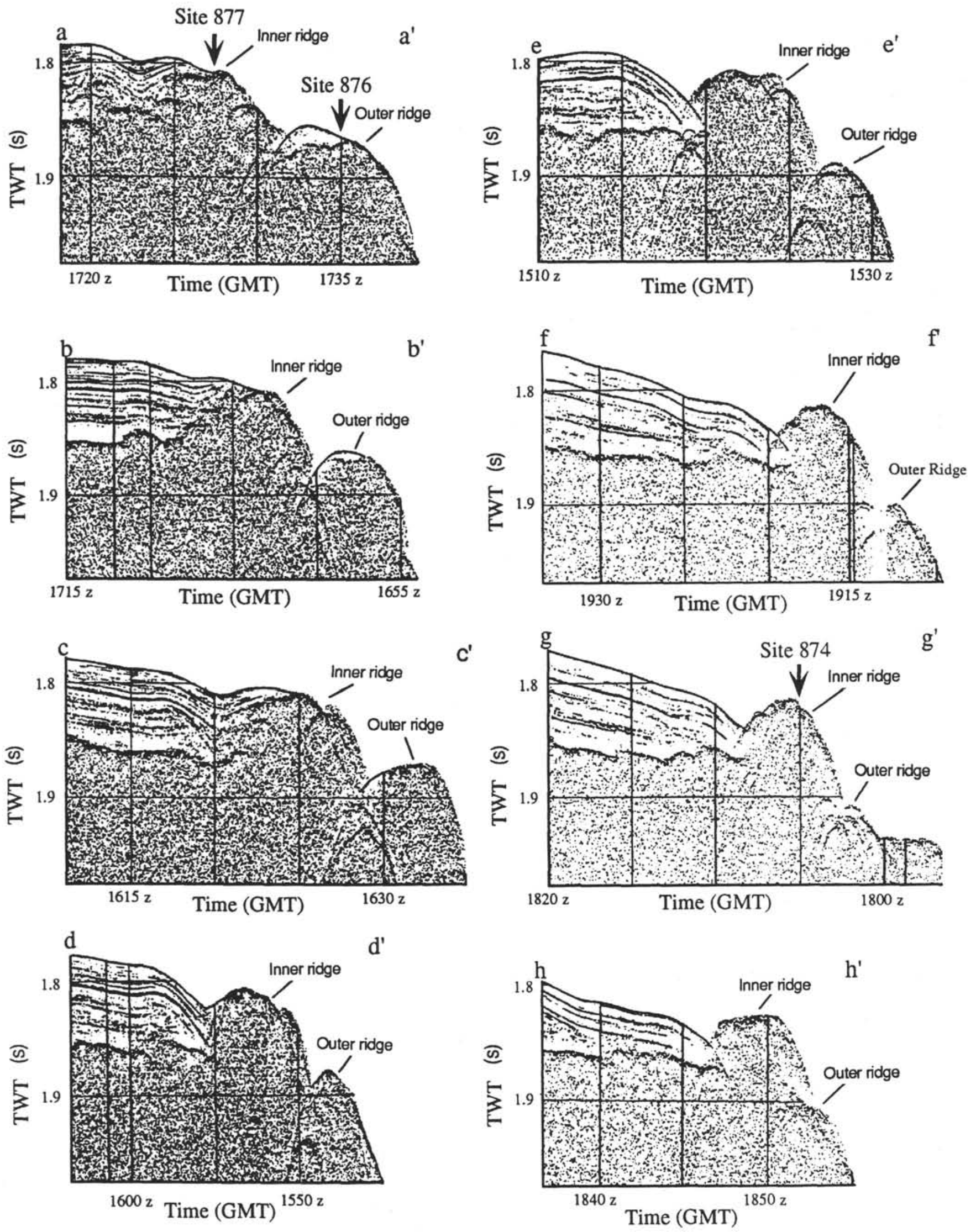

Figure 2. Profiles of 3.5-kHz echo sounder across the perimeter ridges of Wodejebato Guyot. Profiles are arranged from northwest (a-a') to southeast ( $\left.h-h^{\prime}\right)$. The location of Sites 877 and 874 are shown on profiles a-a' and $\mathrm{g}-\mathrm{g}^{\prime}$, respectively. The location of profiles on the guyot is shown in Bergersen (this volume). 


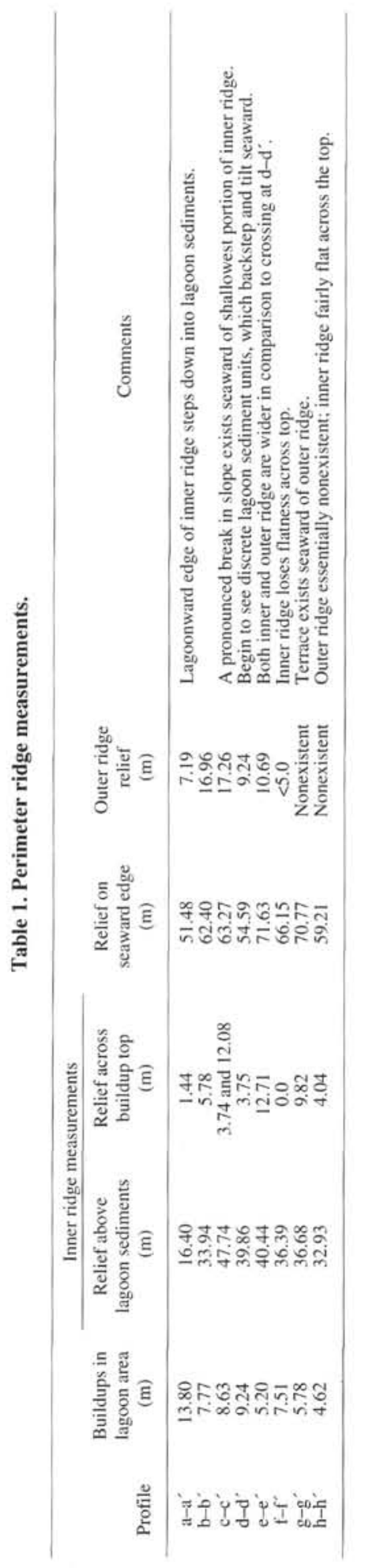

\section{DISTRIBUTION AND PHYSIOGRAPHIC CHARACTERISTICS OF PERIMETER RIDGES}

Bergersen (this volume) provides a detailed discussion of the major geomorphic features composing Wodejebato Guyot. Of relevance to this paper are the perimeter ridges located along the northern edge of the summit plateau, in particular the pair of ridges associated with the shelf formed by the northeastern flank ridge (Fig. 1). The topographic relief of the inner ridge seems to be more accentuated in the vicinity of Site 874 than near Site 877; furthermore, the top of Hole 877A is $19 \mathrm{~m}$ higher (1355 mbsl) than the top of Hole 874B (1374 mbsl). As noted by Bergersen (1993), the inner perimeter ridge appears to cross the edge of the summit plateau in all seismic profiles with the exception of the south flank where faulting has eroded portions of the original edifice. The outer ridge, on the other hand, appears only along the broad shelves formed by the northern and northeastern flank ridges, and along the ridge connecting Wodejebato to Pikinni Atoll. Seismic profiles show that the relief of the perimeter ridges above the surrounding sediments is more pronounced on the northeastern flank ridge (Fig. 1) than on the northern flank ridge (Bergersen, 1993). The top of the volcanic platform can be seen in the 6-channel seismic data (Fig. 1) as a high-amplitude reflector around $1.9 \mathrm{~s}$ TWT (two-way traveltime). Before drilling at Sites 874 and 877, an echo-sounder and singlechannel seismic survey was conducted over the perimeter ridges to better define changing ridge topography and internal structure (Shipboard Scientific Party, 1993a, 1993b; Fig. 2).

Detailed measurements taken from these profiles reveal a number of characteristics about the ridges and the adjacent sediments (Tables $1-2$ ). In the lagoon area, a number of "buildups" range in height from $5 \mathrm{~m}$ and $14 \mathrm{~m}$ (Table 1); some of these "buildups" appear as isolated bumps in cross section (e.g., Fig. 2, profile b- $\mathrm{b}^{\prime}$ ), whereas others are more asymmetric in shape. The asymmetric "buildups" consist of a well-defined seaward-dipping $\left(2^{\circ}\right.$; Table 2$)$ reflector giving way to a steeper but less-defined leeward edge (e.g., Fig. 2, profiles d-d', f-f', $\mathrm{g}-\mathrm{g}^{\prime}$, and $\mathrm{h}-\mathrm{h}^{\prime}$ ). A series of these "buildups" shallow toward the center of the summit plateau in a stair-step fashion. They may be interpreted as sand waves or local buildups and associated sand shoals.

The inner perimeter ridge buttresses and extends above the lagoonal sediments. In the area surveyed during Leg 144, the inner ridge narrows slightly from north $(2 \mathrm{~km})$ to south $(1 \mathrm{~km})$. The maximum height of this ridge above the lagoonal sediments is $48 \mathrm{~m}$, although the average height is $36 \mathrm{~m}$ (Table 1). Slopes on the landward side of the ridge vary from $<1^{\circ}$ up to $10^{\circ}$, whereas those on the seaward side are slightly steeper (up to $15^{\circ}$, Table 2). Breaks in slope occur on both sides of the ridge, ranging from a few meters up to $12 \mathrm{~m}$ below the ridge top. The location of Site 874 is on one of these slope breaks (g- $g^{\prime}$, Fig. 2). The top of the inner perimeter ridge varies in width from less than 100 $\mathrm{m}$ to a maximum of $800 \mathrm{~m}$ (Fig. 2, profile e-e'). Relief on the seaward side of the ridge generally increases to the south as the channel separating the two perimeter ridges becomes wider and deeper. Concomitant with this increase in channel definition is a decrease of the width of the outer ridge (Table 1 ). In the area of profiles $g-g^{\prime}$ and $h-h^{\prime}$ (Fig. 2 ), the outer perimeter ridge appears as a small slope break on the seaward side of the inner perimeter ridge.

\section{STRATIGRAPHY}

\section{Lithostratigraphy}

The thickness of the sedimentary sequence recovered in Hole $874 \mathrm{~B}$ and Hole $877 \mathrm{~A}$ is $177.7 \mathrm{~m}$ and $190.2 \mathrm{~m}$ thick, respectively. Lithologic units were identified by color, carbonate and clay content, fossil and particle constituents, lithification, sedimentary structures, and $\log$ characteristics.

The four major lithologies identified at these sites are, from the top to the bottom (Shipboard Scientific Party, 1993a, 1993b) (Fig. 3): (1) manganese crust and manganese-phosphate coated limestone conglomerate (Site 874 Unit I: Hole 874A, 0-0.14 mbsf, and Hole 874B, 
Table 2. Slope comparisons (in degrees).

\begin{tabular}{|c|c|c|c|c|c|c|}
\hline \multirow[b]{2}{*}{ Profile } & \multicolumn{2}{|c|}{ Inner perimeter ridge } & \multicolumn{2}{|c|}{ Outer perimeter ridge } & \multicolumn{2}{|c|}{ Lagoon reflector } \\
\hline & Upper slope & Lower slope & Upper slope & Lower slope & Maximum & Minimum \\
\hline$a-a^{\prime}$ & 6.7 & 0.9 & 3.7 & 3.7 & NA & NA \\
\hline$b=b^{\prime}$ & 1.6 & 2.4 & 5.6 & 10.2 & NA & NA \\
\hline$c-c^{\prime}$ & 0.8 & 5.1 & 3.2 & 6.2 & NA & NA \\
\hline$d-d^{\prime}$ & 3.3 & 9.8 & 3.2 & 15.3 & 1.40 & 0.95 \\
\hline$e-e^{\prime}$ & 2.2 & 5.9 & 1.6 & 14.5 & $\mathrm{NA}$ & $\mathrm{NA}$ \\
\hline$f-f^{\prime}$ & 6.9 & 3.2 & 2.8 & 8.5 & 1.63 & 1.41 \\
\hline$g-g^{\prime}$ & 2.4 & 9.5 & 3.2 & 9.6 & 1.78 & 0.85 \\
\hline$h-h^{\prime}$ & 0.3 & 9.9 & 7.2 & 7.2 & 1.33 & 0.40 \\
\hline
\end{tabular}

Note: $\mathrm{NA}=$ not analyzed,

0-0.11 mbsf; Site 877-Unit I: Hole 877A, 0-0.03 mbsf), (2) rudistalgal-foraminifer shallow-water limestone (Site 874-Unit II: Hole 874A, 0.14-7 mbsf, and Hole 874B, 0.11-162.8 mbsf; Site 877-Unit II: Hole 877A, 0.03-182.9 mbsf), (3) ferruginous clay, claystone, and extremely altered vesicular basalt (Site 874-Unit III: Hole 874B, 162.8-177.7 mbsf; Site 877-Unit III: Hole 877A, 182.9-190.2 mbsf), and (4) basalt and volcanic breccia. Depth limits among the different lithologic units are discussed herein on the basis of wireline log and FMS data at Site 874. Although the uppermost $25 \mathrm{~m}$ were not logged directly, the calibrated geochemistry log of relative calcium abundance was used as proxy for carbonate density or resistivity.

\section{Biostratigraphy}

At both sites, argillaceous limestone and dark clay (Unit III p.p.), which overlay the weathered volcanic rocks, contain a nannofossil assemblage of late Campanian age (Shipboard Scientific Party, 1993a, 1993b).

Biostratigraphic analysis of platform carbonates relies mainly on larger benthic foraminifers. These constitute successive assemblages including Pseudorbitoides trechmanni, Sulcoperculina sp., and Asterorbis sp. and then Omphalocyclus macroporus Lamarck. The two first assemblages (VI, V, and II on Fig. 3) are late Campanian in age whereas Omphalocyclus (I on Fig. 3), which dominates the last assemblage, characterizes the Maastrichtian (see Premoli Silva et al., this volume). The rudist assemblage recorded in these limestones include radiolitids (Distefanella mooretownensis [Trechmann], Distefanella sp.) and caprinids (Mitrocaprina sp., Coralliochama orcutti White, Coralliochama sp., Plagioptychus aff. fragilis Chubb, $P$. aff. minor Chubb, Antillocaprina sp.), which are reported in CampanianMaastrichtian strata from Jamaica, Mexico, Cuba, and California (Chubb, 1971; Kauffman and Sohl, 1974).

Cavities in platform carbonates are partly filled by pelagic sediments that contain Maastrichtian, early late Paleocene, and early Eocene planktonic foraminifers (Shipboard Scientific Party, 1993a, 1993b). The manganese crust and manganese-phosphate coated conglomerate which cap the shallow-water limestones contain pelagic sediments of various ages ranging from the late Paleocene to the middle Eocene (Shipboard Scientific Party, 1993a, 1993b).

\section{WEATHERING PROFILES OF VOLCANIC SUBSTRATE AND INITIAL MARINE DEPOSITS}

The first sedimentary deposits directly overlying the volcanic substrate consist of claystone breccia, claystone, organic-rich clay, and argillaceous limestone (Figs. 3-4), 14 and $7.3 \mathrm{~m}$ thick at Sites 874 and 877, respectively (Site 874: Unit III-interval from Section 144-874B21R-1, $2 \mathrm{~cm}$, through Core 144-874B-22R, 162.82-177.7 mbsf; Site 877: Unit III-interval from Section 144-877A-20R-1, $20 \mathrm{~cm}$, to Section 144-877A-20R-4, $110 \mathrm{~cm}, 182.9-190.2 \mathrm{mbsf}$ ). The top of the clay of lithologic Unit III is at 161.4 mbsf on the BRG-Lamontprocessed FMS imagery. This compares to $162.8 \mathrm{mbsf}$ on the shipboard preliminary processed FMS imagery, which was adjusted according to the position of this clay-to-limestone boundary ( $162.4 \mathrm{mbsf})$ in the resistivity logs from the geophysical tool. The top of the clay unit is at the top of Core 144-874B-21R (162.8 mbsf), although it may actually be at a higher level near the unrecovered base of overlying Core 144-874B-20R. Based upon this comparison, it seems that the depths of the BRG-Lamont-processed FMS imagery are about $1 \mathrm{~m}$ higher than the other records. The sharp contact between clays and overlying platform carbonates at 161.4 mbsf dip slightly (a few degrees) toward the southeast as other beds within the Clay Unit.

The claystone breccia (interval $144-877 \mathrm{~A}-20 \mathrm{R}-4,0-110 \mathrm{~cm}$ ) is composed of dusky red to reddish brown angular clasts ranging in size from $1 \mathrm{~mm}$ up to $4 \mathrm{~cm}$. The overlying claystone is dark, brownish and gray within an olive green clayey matrix (interval from Section 144877 A-20R-2, $132 \mathrm{~cm}$, to $-20 \mathrm{R}-3,90 \mathrm{~cm}$ ). Pyrite is common in the matrix (up to $4 \%$ ) and forms small aggregates. Roots are preserved in interval $144-877$ A-20R-2, 46-120 cm. The dusky red to gray clay and claystone, which form the bulk of Unit III in both sites, is interpreted as a subaerial weathering profile of the basalt. The contact between the basalt and the clay is gradational and the degree of alteration decreases downward. This is consistent with the enrichment in iron and silica recorded by the gamma spectrometer log (Fig. 3). The texture of the former igneous breccia (interval 144-877A-20R-4, $100-110 \mathrm{~cm}$ ) or altered basalt, including laths of plagioclase and vesicles filled by white patches of zeolites (e.g., interval 144-874B$22 \mathrm{R}-3,85-127 \mathrm{~cm}$ ) is locally preserved in the clay and claystone. The subaerial weathering profile formed by clay and claystone is thinner at Site 877 (6.5 m thick; Sections 144-877A-20R-2 through -20R-4; depths, $183.7-190.2 \mathrm{mbsf})$ than at Site 874 (14.5 m thick; interval from Section 144-874B-21R-1, $41 \mathrm{~cm}$, through Core 144-874B-22R), possibly as a result of the higher substrate relief of Site 877 .

The formation and preservation of the peat reported in interval 144-877A-20R-2, 0-20 cm, may represent the first influences of marine waters. The high sulfur content of this peat is probably related to the bacterial reduction of sulfates provided by marine waters; preservation of plant debris in this peat suggests the prevalence of lowenergy conditions. The organic-rich clay (intervals 144-874B-21R-1, 2-41 cm; 144-877A-20R-1, 20-32 cm; and 144-877A-20R-1, 77-100 $\mathrm{cm}$ ) is gray to black with preserved kerogen-type woody material and also includes calcareous nannofossils and larger foraminifers. The argillaceous limestone that forms the top of Unit III at Site 877 (interval 144-877A-20R-1, 32-77 cm) are intercalated with laminae of black clay and contains few thin-shelled mollusc fragments and rare benthic foraminifers. The depositional environment corresponds to a quiet shallow-marine environment, as suggested by the preservation of clay and the lack of any reworking at the base of marine deposits.

\section{SHALLOW-WATER PLATFORM CARBONATES}

\section{Facies Model}

The Campanian-Maastrichtian platform carbonates (161.4 and $182.6 \mathrm{~m}$ thick at Sites 874 and 877 , respectively) consist of interbedded grainstone shoal, rudist-coralgal framework, and "lagoonal" wackestone complexes (Figs. 3-4). The greater thickness of the carbonate sequence at Site 877 (18.6 m thicker than at Site 874$)$ results from the thickening of the lower "reef" unit that makes up most of the upper half of the platform carbonate sequence (Hole 874B: Subunit IIC, $42 \mathrm{~m}$ 

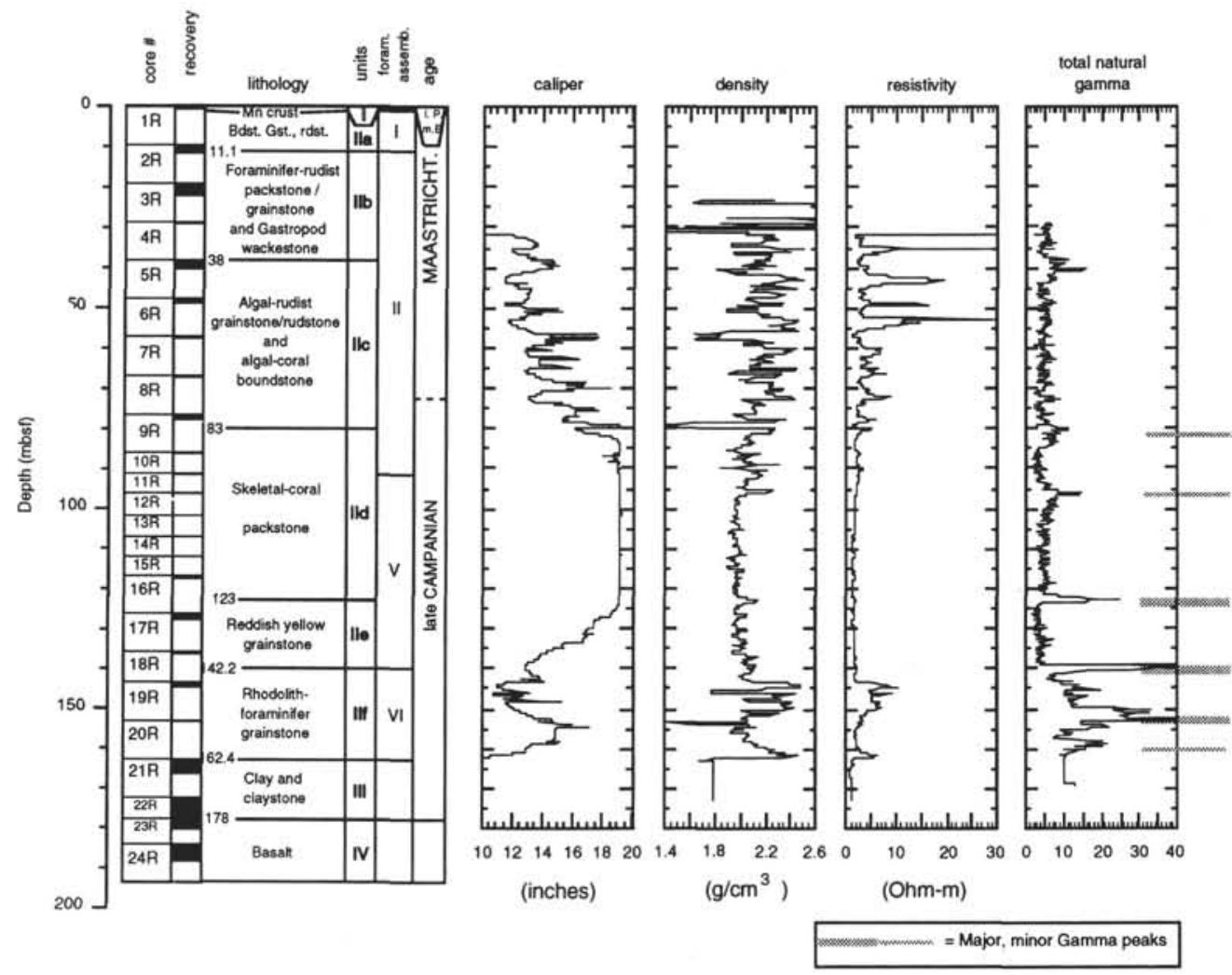

Figure 3. Stratigraphy of Hole 874B from selected geophysical logs as compared with cored intervals, lithostratigraphy, and biostratigraphic ages. Resistivity is from the medium-penetration phasor-induction (IMPH) tool. Total natural gamma measurements are from the FMS run. Caliper or apparent hole diameter does not record values greater than $48 \mathrm{~cm}$.

thick; Hole 877A: Subunit IIC, $77.3 \mathrm{~m}$ thick). This elevational difference between the two sites may result either from the differential organic growth or from late erosion processes.

The following summary of the carbonate facies integrates the observations from the cored sediments (typically much less than $1 \mathrm{~m}$ of recovery from each 10 -m-cored interval), the quantitative resistivity measurements, the natural-gamma intensities, and the detailed FMS "textures" (darkness on gray-scale imagery) expressed in a shorthand of "low" (<2 ohm-m), "medium" ( $2-5$ ohm-m) and "high" ( $>5$ ohm-m) resistivity. Division of the lithologic succession into subunits is based initially on the facies and nomenclature of shipboard-defined lithologic units. Grain counting data and subsequent correspondence analysis data are shown in Figures 5 and 6, where an environmental gradient appears with a clear component relay on Axis 1.

\section{Sand Shoals}

\section{Occurrence}

This facies constitutes Subunits IID to IIF at Site 874 (interval from Core 144-874B-10R to Section 144-874B-21R-1, 2 cm, 83$162.82 \mathrm{mbsf}$ ) and Subunits IID and IIE at Site 877 (interval from Core 144-877A-12R to Section 144-877A-20R-1, $20 \mathrm{~cm}, 105.7-182.9$ mbsf) (Fig. 4).

In Subunit IIF, $19 \mathrm{~m}$ thick (142.4-161.4 mbsf), the resistivity curve displays three main features (Fig. 3): (1) a basal peak in resistivity followed by a sharp drop, (2) a multipeaked interval of medium resistivity, and (3) a major high-resistivity peak. Natural gamma is at a relatively high intensity throughout this subunit, with maximum values at $149.0-153.0 \mathrm{mbsf}$. This high gamma value is associated with a facies of algal flats and concretions. The top of Subunit IIF may correspond to a cemented horizon.
The boundaries of reddish yellow grainstone from Subunit IIE were originally placed at major peaks in natural gamma-ray intensity, which were thought to coincide with surfaces of cementation. However, later BRG-Lamont depth corrections indicate that the lower major peak in uranium concentration is centered at about $140 \mathrm{mbsf}$, $2.5 \mathrm{~m}$ above the pronounced cementation surface at $142.2 \mathrm{mbsf}$, and appears to coincide with an algal-rich interval. Subdivisions were made relative to the lower peak in uranium concentration. The caliper of borehole diameter progressively opens between these two uranium peaks, and is wider from 123 to 92 mbsf (Fig. 3).

\section{Description}

Subunit IID is essentially a featureless low-resistivity facies, except for the uppermost $7 \mathrm{~m}$ where resistivity gradually increases (Fig. $3)$. The contact between these two logging subunits is marked by a minor peak in gamma-ray intensity. Based on well-log data, the upper boundary of this lithologic Subunit IID is placed at the top of the medium-resistivity facies ( $89.1 \mathrm{mbsf}$ ), where it is sharply overlain by a low-resistivity interbedded facies that is more typical of a basal portion of the "upward-shallowing cycles" that characterize the overlying lithologic Subunit IIC.

Sand shoal facies primarily consist of white, pink, yellow, and reddish yellow, fine-grained skeletal packstone and grainstone ( $\mathrm{Pl}$. 1A). The FMS signature of this facies is a very poorly cemented, massive grainstone to "rubble-speckled" deposit without significant bedding or cementation levels. Grain size averages $0.1-1.5 \mathrm{~mm}$, and the sorting, usually poor, may be locally bimodal (mixing fine sands and coarse sands or gravels); grains are usually angular to subangular. Major components of these skeletal packstone and grainstone include benthic foraminifers (orbitoidids, Sulcoperculina and miliolids, lituolids, textulariids), fragments of red algae (corallinaceans, few frag- 


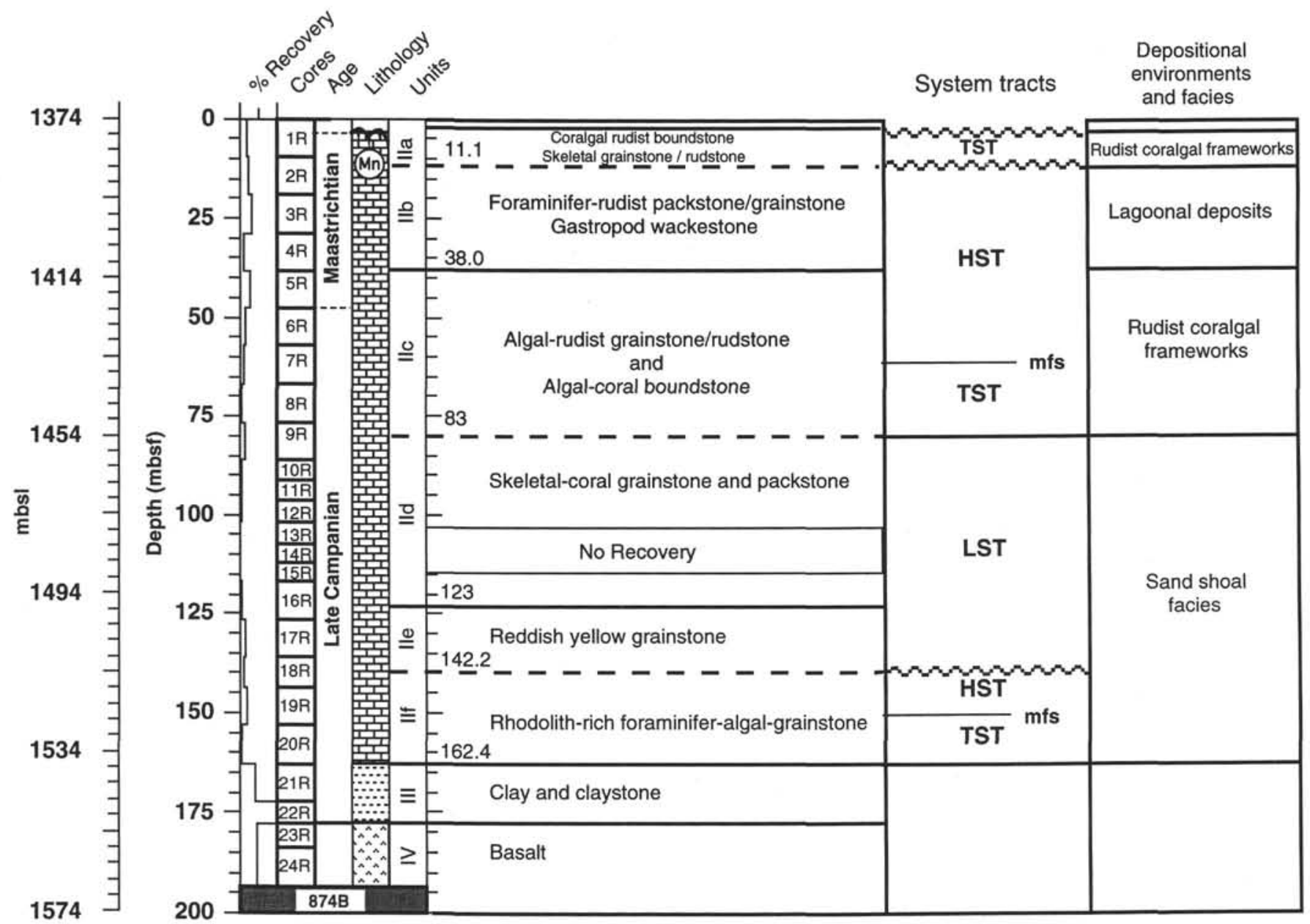

Figure 4. Stratigraphy of Hole 874B with lithostratigraphy, biostratigraphic ages, systems tracts, and interpretation of depositional environments and facies.

ments of solenoporaceans and peyssonneliaceans), rudists (radiolitids), and other bivalves (inocerames and pycnodonts) (Fig. 5 and Tables 3-4). Large fragments of corals and rhodoliths, $1.0-1.5 \mathrm{~cm}$ in diameter, are locally common. There are few fragments of green algae (dasycladaceans, codiaceans), gastropods, bryozoans, and echinoderms. Calcisphaerulids and scarce planktonic foraminifers are noted locally. A few lithoclasts consist of micrite with benthic foraminifers and comminuted fragments of rudists and red algae.

\section{Interpretation}

The fossil content and sedimentologic criteria imply a shallowmarine depositional environment with moderate-to-high energy conditions. The vague oblique and low-angle cross laminations noted locally on cores (e.g., intervals 144-874B-17R-1, 36-44 cm, and 144-874B-17R-1, 47-53 cm) as well as the imbrication of large clasts suggest the prevalence of a sedimentary regime dominated by currents and the occurrence of sedimentary slopes. The changes in texture and in the relative abundance of organisms (increasing abundance of benthic foraminifers coeval with a decrease in the abundance of rudists and red algae) recorded at the Subunit IIE-Subunit IID transition at Site 874 suggest a slight decrease in wave energy. The local dusky red color is primarily related to irregular impregnations of iron oxides both in matrix and in cavities, which could result from either a very slow sedimentation and associated oxidation or pervasive weathering. The possibility of reddish coloration caused by surficial weathering and "Terra Rosa" soil development was not supported by microfacies (no vadose-style cement development), nor by isotopes (no vadose signature), nor by chemistry (no thorium or silica/aluminum increase suggesting soil clays).

The abundance of red algal balls and nodules reported at the base of the carbonate sequence (e.g., Section $874 \mathrm{~B}-18 \mathrm{R}-21 \mathrm{R}-1,2 \mathrm{~cm}$ ) is a common feature in the initial steps of development of CampanianMaastrichtian isolated carbonate platforms (Camoin et al., 1988) and Cenozoic atolls (Bourrouilh, 1979; Collot, Greene, Stokking, et al., 1992). As recent rhodolites, these nodules seemingly played a significant role in the stabilization of previously mobile substrates.

\section{Rudist-coral Frameworks and Associated Bioclastic}

\section{Shoals Occurrence}

These facies constitute two distinct "reef" intervals at both sites (Fig. 4): a lower one comprises Subunit IIC (Cores 144-874B-5R to $-9 \mathrm{R}, 38.1-83$ mbsf; Cores $144-877 \mathrm{~A}-4 \mathrm{R}$ to $-11 \mathrm{R}, 28.4-105.7 \mathrm{mbsf}$ ) and an upper one constitutes Subunit IIA (interval from Section 144874B-1R-1, $11 \mathrm{~cm}$, to Section 144-874B-2R-1, $140 \mathrm{~cm}, 0.11-11.1$ mbsf; and Core 144-877A-1R, 0.03-9.5 mbsf). Although the existence of a true framework is difficult to ascertain in cores, the facies involved consist of closely associated rudist-coralgal frameworks and bioclastic units. The FMS shows a series of stacked horizontal elongate deposits of high resistivity (coral-algal-rudist frameworks), alternating with less-resistant material (skeletal grainstones and rudstones) (Fig. 3).

\section{Description}

The lower interval is composed of algal-rudist grainstone/ rudstone, with a few packstone layers and algal-coral boundstone. 
Table 3. Grain-counting data of skeletal components of shallow-water carbonates at Site 874.

\begin{tabular}{|c|c|c|c|c|c|c|c|c|c|c|c|c|}
\hline Subunit & $\begin{array}{l}\text { Core, section } \\
\text { interval }(\mathrm{cm})\end{array}$ & $\begin{array}{l}\text { Depth } \\
\text { (mbsf) }\end{array}$ & Texture & $\begin{array}{l}\text { RDA } \\
(\%)\end{array}$ & $\begin{array}{l}\text { GRA } \\
\text { (\%) }\end{array}$ & $\begin{array}{l}\text { BTF } \\
(\%)\end{array}$ & $\begin{array}{l}\text { COR } \\
(\%)\end{array}$ & $\begin{array}{l}\text { RDT } \\
(\%)\end{array}$ & $\begin{array}{l}\text { BIV } \\
(\%)\end{array}$ & $\begin{array}{l}\text { GTP } \\
(\%)\end{array}$ & $\begin{array}{l}\text { OST } \\
(\%)\end{array}$ & $\begin{array}{l}\mathrm{ECH} \\
(\%)\end{array}$ \\
\hline Ila & $1 \mathrm{R}-1,25-29$ & 0.27 & G & 0 & 6.7 & 20.8 & 20.8 & 0 & 34.0 & 0.5 & 0.5 & 0.5 \\
\hline Ila & IR-1, 35-39 & 0.37 & G & 0 & 5.5 & 28.2 & 18.6 & 1.9 & 9.1 & 0 & 5.0 & 5.0 \\
\hline $\mathrm{IIa}$ & IR-1,56-61 & 0.59 & $\mathrm{R}$ & 0 & 1.0 & 31.0 & 63.0 & 0 & 0 & 0 & 0 & 0 \\
\hline IIa & IR-1, 83-90 & 0.86 & $\mathrm{R}$ & 0 & 1.7 & 15.6 & 44.0 & 0.5 & 0 & 0 & 0 & 0 \\
\hline Ila & IR-1, $122-128$ & 1.25 & B & 0 & 1.2 & 32.0 & 1.0 & 1.0 & 0 & 0 & 0 & 0 \\
\hline IIa & $2 \mathrm{R}-1,25-30$ & 9.98 & $\mathrm{~F}$ & 0.2 & 32.2 & 0.7 & 14.0 & 1.5 & 32.0 & 1.2 & 1.2 & 1.2 \\
\hline IIa & $2 \mathrm{R}-1,69-70$ & 10.40 & $\mathrm{P}$ & 0 & 39.0 & 0.5 & 39.8 & 0 & 8.7 & 0.5 & 10.0 & 10.0 \\
\hline Ila & $2 \mathrm{R}-1,96-100$ & 10.68 & $\mathrm{P}$ & 13.8 & 30.0 & 0.2 & 46.9 & 2.3 & 0.7 & 0 & 2.0 & 2.0 \\
\hline $1 \mathrm{Ilb}$ & $2 \mathrm{R}-2,12-17$ & 11.26 & F & 0 & 22.0 & 29.0 & 27.8 & 0 & 4.7 & 0 & 4.5 & 4.5 \\
\hline $\mathrm{IIb}$ & $2 \mathrm{R}-2,47-55 \mathrm{~A}$ & 11.72 & $\mathrm{P}$ & 13,1 & 28.8 & 0 & 26.3 & 0.2 & 12.5 & 1.2 & 6.3 & 6.3 \\
\hline $\mathrm{Ilb}$ & $2 \mathrm{R}-2,47-55 \mathrm{~B}$ & 11.72 & W & 6.3 & 40.0 & 0 & 19.0 & 3.7 & 12.0 & 16.0 & 3.0 & 3.0 \\
\hline $\mathrm{IJb}$ & $3 R-1,0-4$ & 19.22 & w & 0 & 31.8 & 0 & 67.4 & 0 & 0 & 0.8 & 0 & 0 \\
\hline IIb & $3 \mathrm{R}-1,43-49$ & 19.66 & G & 0 & 22.7 & 6.0 & 63.0 & 1.1 & 4.0 & 0 & 1.0 & 1.0 \\
\hline $\mathrm{IIb}$ & $3 \mathrm{R}-1,84-96$ & 20.10 & W/P & 0 & 51.3 & 0.5 & 36.0 & 2.4 & 0 & 2.2 & 2.5 & 2.5 \\
\hline $\mathrm{IIb}$ & $3 \mathrm{R}-1,130-134$ & 20.52 & $\mathrm{P}$ & 0 & 57.7 & 0.7 & 35.4 & 5 & 0 & 0 & 0.7 & 0.7 \\
\hline $\mathrm{IIb}$ & $3 R-2,0-3$ & 20.69 & $\mathrm{P}$ & 0 & 70.5 & 0 & 25.8 & 0 & 0 & 0 & 3.7 & 3.7 \\
\hline IIb & $3 \mathrm{R}-2,48-52$ & 21.17 & $\mathrm{P}$ & 0 & 31.0 & 2.1 & 32.0 & 0 & 0 & 0.5 & 10.5 & 10.5 \\
\hline $\mathrm{IIb}$ & $3 R-3,8-11$ & 22.20 & & 0 & 62.2 & 0 & 24.1 & 0 & 1.7 & 0.2 & 4.5 & 4.5 \\
\hline $\mathrm{IJb}$ & $3 \mathrm{R}-3,19-22 \mathrm{~A}$ & 22.30 & $\mathrm{P}$ & 0 & 53.0 & 0 & 23.0 & 0 & 0.3 & 0 & 13.3 & 13.3 \\
\hline IIb & $3 \mathrm{R}-3,19-22 \mathrm{~B}$ & 22.30 & w & 0 & 66.1 & 0 & 2.0 & 3.1 & 10.8 & 17.0 & 1.0 & 1.0 \\
\hline IIb & $3 \mathrm{R}-3,3 \mathrm{l}-33$ & 22.42 & P & 0 & 33.4 & 6.2 & 53.8 & 0 & 0.2 & 0.2 & 2.5 & 2.5 \\
\hline $\mathrm{IIb}$ & $4 \mathrm{R}-1,16-18$ & 28.87 & W/M & 0 & 65.5 & 0 & 1.4 & 1.4 & 5.7 & 25 & 0.5 & 0.5 \\
\hline $\mathrm{IIb}$ & $4 \mathrm{R}-1,23-31$ & 28.97 & W & 0.8 & 68.0 & 0.2 & 14.7 & 0 & 7.2 & 3.7 & 5.2 & 5.2 \\
\hline Ilb & $4 \mathrm{R}-1,66-75$ & 29.40 & G & 0 & 22.3 & 10.7 & 54.0 & 2.7 & 4.0 & 0 & 2.0 & 2.0 \\
\hline IIc & $5 R-1,17-22$ & 38.30 & $\mathrm{G} / \mathrm{R}$ & 0 & 28.7 & 5.2 & 53.0 & 0 & 4.5 & 0 & 5.5 & 5.5 \\
\hline IIc & $5 \mathrm{R}-1,28-32$ & 38.40 & B & 0 & 15.0 & 4.5 & 57.0 & 0 & 8.0 & 0 & 7.5 & 7.5 \\
\hline IIc & $5 \mathrm{R}-1,39-44 \mathrm{~A}$ & 38.52 & B & 0 & 19.0 & 4.1 & 57.0 & 0 & 8.2 & 0 & 2.5 & 2.5 \\
\hline Ilc & $5 \mathrm{R}-1,39-44 \mathrm{~B}$ & 38.52 & B & 4.6 & 14.3 & 10.2 & 46.8 & 0 & 0 & 0 & 8.7 & 8.7 \\
\hline IIc & $5 \mathrm{R}-1,49-55$ & 38.62 & $\mathrm{P}$ & 0 & 27.0 & 9.4 & 40.0 & 0 & 0.5 & 0 & 9.4 & 9.4 \\
\hline IIc & $5 \mathrm{R}-1,80-83$ & 38.92 & $\mathrm{G} / \mathrm{P}$ & 0 & 16.0 & 10.5 & 40.5 & 3.0 & 0 & 0 & 25.2 & 25.2 \\
\hline IIc & $5 \mathrm{R}-1,145-149$ & 39.57 & $\mathrm{P}$ & 0 & 42.0 & 2.1 & 34.9 & 0 & 0.7 & 0 & 10.7 & 10.7 \\
\hline IIc & $5 \mathrm{R}-2,20-24$ & 39.81 & $\mathrm{P}$ & 1.2 & 37.0 & 0 & 28.0 & 0 & 16.7 & 0 & 15.9 & 15.9 \\
\hline IIc & $5 \mathrm{R}-2,85-88$ & 40.46 & $\mathrm{P}$ & 0.5 & 33.4 & 0.2 & 47.0 & 0 & 0.7 & 0.7 & 12.5 & 12.5 \\
\hline Ilc & $5 R-2,102-108$ & 40.64 & $\mathrm{P} / \mathrm{F}$ & 0 & 11.0 & 12.0 & 60.3 & 4.0 & 8.2 & 0.5 & 2.5 & 2.5 \\
\hline IIc & $6 \mathrm{R}-1,16-19$ & 47.78 & $\mathrm{G}$ & i & 38.0 & 6.0 & 37.0 & 0 & 2.0 & 0 & 10.0 & 10.0 \\
\hline IIc & $6 \mathrm{R}-1,47-52$ & 48.10 & G & 0 & 30.0 & 9.0 & 29.3 & 0 & 2.7 & 0 & 10.0 & 10.0 \\
\hline IIc & $6 \mathrm{R}-1,61-63$ & 48.22 & G & 0 & 17.0 & 11.7 & 40.0 & 0.5 & 0 & 0 & 20.8 & 20.8 \\
\hline Ilc & $6 \mathrm{R}-1,64-67$ & 48.25 & $B / P$ & 0 & 10.0 & 41.0 & 33.0 & 0 & 0 & 0 & 8.5 & 8.5 \\
\hline $\begin{array}{l}\text { IIc } \\
\text { If }\end{array}$ & $6 \mathrm{R}-1,82-86$ & 48.44 & $\mathrm{G} / \mathrm{P}$ & 0 & 22.8 & 8.0 & 53.0 & 0 & 1.7 & 0 & 4.2 & 4.2 \\
\hline IIc & $6 \mathrm{R}-1,97-103$ & 48.60 & $\mathrm{P} / \mathrm{F}$ & 0 & 7.2 & 4.5 & 69.3 & 0 & 0 & 0 & 5.0 & 5.0 \\
\hline IIc & $6 \mathrm{R}-1,103-106$ & 48.64 & B & 0 & 1.8 & 2.6 & 77.0 & 0 & 0 & 0 & 4.5 & 4.5 \\
\hline Ilc & $6 \mathrm{R}-1,122-126$ & 48.84 & B & 0 & 6.0 & 0 & 83.0 & 0.8 & 0.8 & 0 & 3.0 & 3.0 \\
\hline IIc & $6 \mathrm{R}-1,138-141$ & 49.00 & $\mathrm{~F}$ & 0 & 10.8 & 31.5 & 23.7 & 0.5 & 0 & 0 & 5.2 & 5.2 \\
\hline IIc & $6 \mathrm{R}-2,24-26$ & 49.32 & B & 0 & 6.1 & 66.4 & 1.3 & 0 & 0.7 & 0 & 2.5 & 2.5 \\
\hline Ilc & $7 \mathrm{R}-1,5-10$ & 57.28 & B & 0 & 7.0 & 83.6 & 1.6 & 0 & 0 & 0 & 5.0 & 5.0 \\
\hline IIc & $7 \mathrm{R}-1,26-31$ & 57.49 & $\mathrm{G} / \mathrm{B}$ & 0 & 43.0 & 32.8 & 9.4 & 0 & 0 & 0 & 8.5 & 8.5 \\
\hline IIc & $7 \mathrm{R}-1,59-62$ & 57.80 & $\mathrm{~B} / \mathrm{G} / \mathrm{P}$ & 0 & $\begin{array}{l}43.0 \\
17.9\end{array}$ & 26.3 & 2.1 & 0 & 0 & 0 & 4.5 & 4.5 \\
\hline II & $8 \mathrm{R}-1,18-21$ & 67.10 & B & 0 & 16.2 & 0 & 0.7 & 0 & 0 & 0 & 2.2 & 2.2 \\
\hline IIc & $9 R-1,3-7$ & 76.65 & B & 0 & 18.9 & 8.0 & 2.1 & 0 & 0 & 0 & 8.2 & 8.2 \\
\hline IIc & $9 \mathrm{R}-1,50-53$ & 77.11 & B & 0 & 16.0 & 17.5 & 0.2 & 0 & 0 & 0 & 2.7 & 2.7 \\
\hline IIc & $9 \mathrm{R}-1,107-110$ & 77.68 & $\mathrm{G} / \mathrm{P}$ & 0 & 74.6 & 0 & 3.0 & 0 & 0 & 0 & 11.2 & 11.2 \\
\hline IIc & $9 \mathrm{R}-2,4-5$ & 78.12 & $\mathrm{P} / \mathrm{G}$ & 0 & 53.8 & 0 & 18.0 & 0 & 0 & 0 & 12.2 & 12.2 \\
\hline IId & $10 R-1.7-10$ & 86.28 & $\mathrm{~B} / \mathrm{P}$ & 0 & 4.7 & 92.3 & 0.2 & 0 & 0 & 0 & 1.0 & 1.0 \\
\hline IId & $11 \mathrm{R}-1,4-7$ & 91.25 & $\mathrm{P}$ & 0 & 34.0 & 18.0 & 14.5 & 0 & 1.7 & 0 & 15.7 & 15.7 \\
\hline IId & $16 R-1,16-20$ & 116.98 & G & 0 & 9.5 & 0.2 & 57.0 & 0 & 0 & 0 & 9.5 & 9.5 \\
\hline IId & $16 \mathrm{R}-1,44-47$ & 117.25 & $\mathrm{G}$ & 0 & 9.3 & 0.3 & 66.7 & 0 & 0 & 0 & 18.0 & 18.0 \\
\hline $\mathrm{Hle}$ & $17 \mathrm{R}-1,47-55$ & 126.90 & G & 0 & 17.3 & 0 & 35.3 & 0 & 0 & 0 & 25.1 & 25.1 \\
\hline $\mathrm{Ile}$ & 17R-1. $95-99$ & 127.37 & G & 0 & 17.5 & 0 & 21.5 & 3.0 & 0 & 0 & 20.0 & 20.0 \\
\hline IIe & $18 \mathrm{R}-1,12-16$ & 136.14 & G & 0.5 & 18.0 & 0 & 31.0 & 7.0 & 0 & 0 & 16.5 & 16.5 \\
\hline Ile & $18 \mathrm{R}-1,53-55$ & 136.54 & G & 0.8 & 14.5 & 0 & 18.0 & 4.4 & 0 & 0 & 8.8 & 8.8 \\
\hline IIf & $19 R-1,16-20$ & 143.68 & p & 3.4 & 30.6 & 0.2 & 1.1 & 0.5 & 0 & 0 & 8.2 & 8.2 \\
\hline IIf & $19 \mathrm{R}-1,31-35$ & 143.83 & B & 0 & 7.1 & 6.8 & 0 & 0 & 4.2 & 0 & 0 & 0 \\
\hline IIf & $19 R-1,93-99$ & 144.46 & B & 0 & 6.0 & 8.7 & 4.7 & 1.0 & 0.2 & 0 & 3.7 & 3.7 \\
\hline IIf & $19 \mathrm{R}-1,145-149$ & 144.97 & G & 0.6 & 39.0 & $\begin{array}{l}0.1 \\
0\end{array}$ & 2.3 & 0 & 0 & 0 & 6.7 & 6.7 \\
\hline IIf & $20 \mathrm{R}-1,5-7$ & 153.16 & G & 0 & 35.1 & 3.4 & 3.4 & 0 & i. 0 & 0 & 0 & 0 \\
\hline
\end{tabular}

Notes: $\mathrm{RDA}=$ red algae, $\mathrm{GRA}=$ green algac, $\mathrm{BTF}=$ benthic foraminifers, $\mathrm{COR}=$ corals. $\mathrm{RDT}=$ rudists, $\mathrm{BIV}=$ other bivalves, $\mathrm{GTP}=$ gastropods, $\mathrm{OST}=\mathrm{ostracodes}, \mathrm{ECH}=\mathrm{echinoids}$, $\mathrm{G}=$ grainstones, $\mathrm{P}=$ packstones, $\mathrm{W}=$ wackestones, $\mathrm{M}=$ mudstones, $\mathrm{B}=$ boundstones, $\mathrm{R}=$ rudstones, and $\mathrm{F}=$ floatstones.

Core recovery and FMS imagery suggest that these facies are interbedded and constitute eight major cycles, with a general "saw-tooth" pattern of resistivity caused by differential cementation. These cycles are characterized by a progressive upward increase in resistivity (i.e., gradational change from porous grainstone and rudstone to more cemented boundstone), probably reflecting minor fluctuations in environmental conditions (i.e., hydrodynamic conditions) and/or the distribution of building organisms. Intervals with sustained moderate natural gamma-ray intensity correspond to algal-rich facies (78.885.0 mbsf). On the basis of well-log data, the upper limit of Subunit IIC at Site 874 should be placed at $41.3 \mathrm{mbsf}$ instead of at $38.1 \mathrm{mbsf}$, as reported by the Shipboard Scientific Party (1993a).
Bioclastic facies corresponds to poorly sorted skeletal grainstone/ rudstone (Pl. 1B) or packstone/floatstone, depending on the occurrence of secondary peloidal micrite, which frequently exhibits a geopetal pattern. Grain size generally ranges from $0.1 \mathrm{~mm}$ up to a few millimeters, and grains are well rounded. Major skeletal components include rudists (radiolitids: Distefanella mooretownensis [Trechmann], Distefanella sp.; caprinids: Mitrocaprina sp., Coralliochama sp., Plagioptychus sp.), red algae (Corallinaceans, Solenoporaceans, Peyssonneliaceans), and benthic foraminifers (Sulcoperculina, Asterorbis; miliolids: Triloculina and Quinqueloculina; discorbids; lituolids: Ammobaculites; rotaliids; and small textulariids) (Fig. 5 and Tables 3-4). Rudists are generally fragmented, except the small radiolitids, which 
Table 4. Grain-counting data of skeletal components of shallow-water carbonates at Site 877.

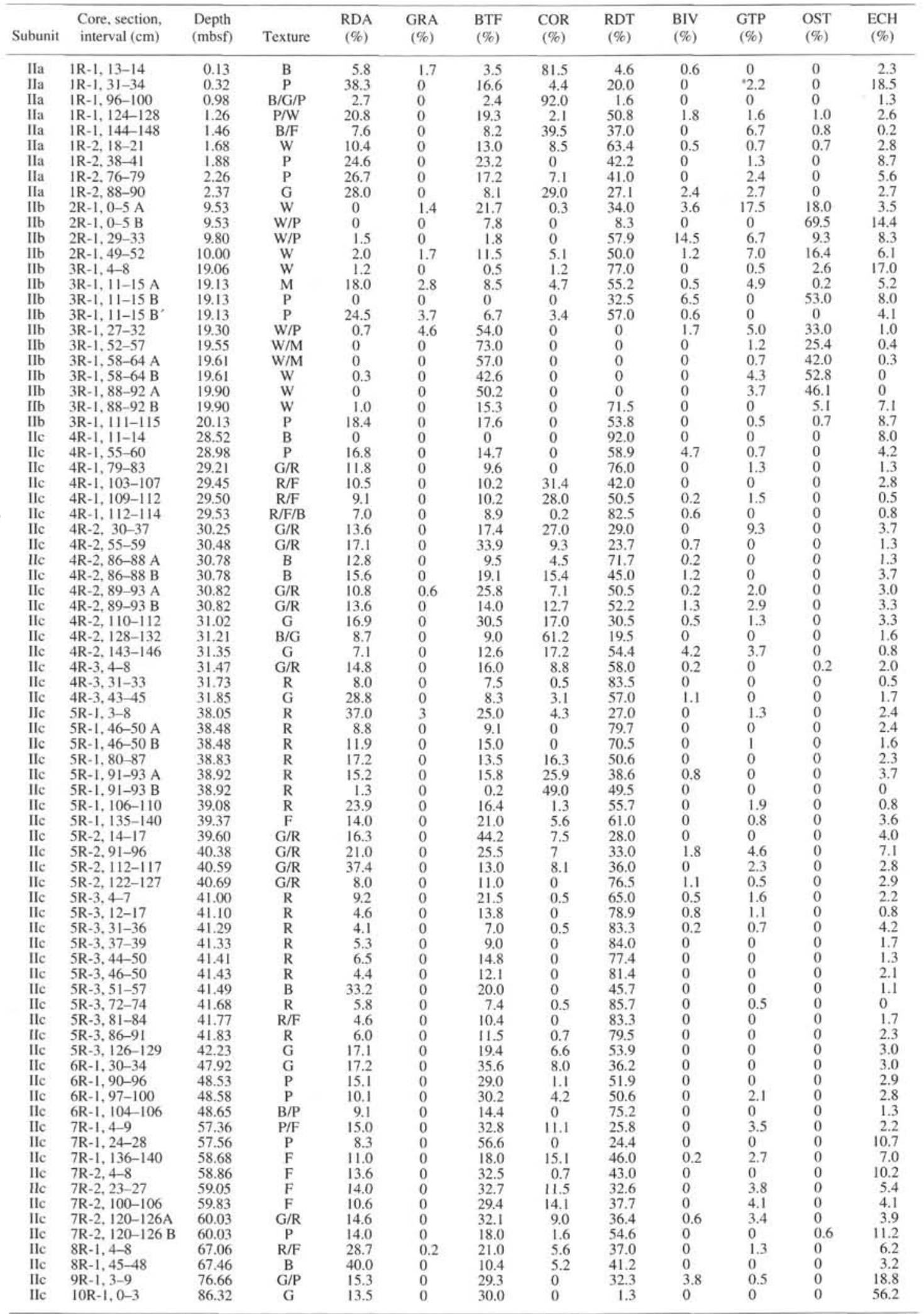

Notes: $\mathrm{RDA}=$ red algae, $\mathrm{GRA}=$ green algae, $\mathrm{BTF}=$ benthic foraminifers, $\mathrm{COR}=$ corals, $\mathrm{RDT}=$ rudists, $\mathrm{BIV}=$ other bivalves, GTP $=$ gastropods, $\mathrm{OST}=$ ostracodes, $\mathrm{ECH}=\mathrm{echinoids}$. $\mathrm{G}=$ grainstones, $\mathrm{P}=$ packstones, $\mathrm{W}=$ wackestones, $\mathrm{M}=$ mudstones, $\mathrm{B}=$ boundstones, $\mathrm{R}=$ rudstones, and $\mathrm{F}=$ floatstones. 

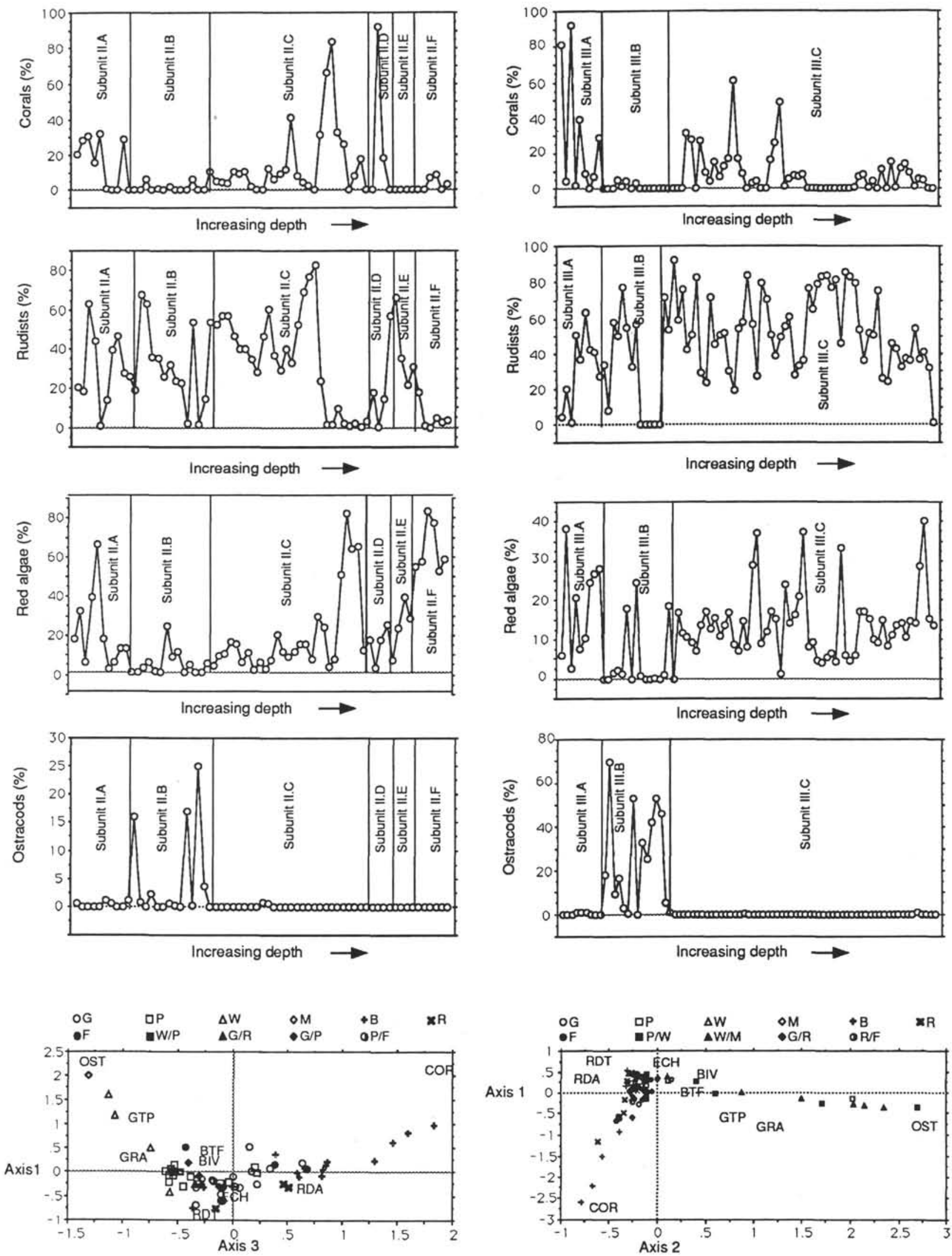

Site 874

Site 877

Figure 5. Abundance of major component grain-type (variables) plotted vs. depths and subunits. The two lower figures show correspondence analysis plot in the plane of Axes 1 and 3 at Site 874 and Axes 1 and 2 at Site 877. Note the arch effect indicating a relay (see Hennebert and Lees, 1991). 

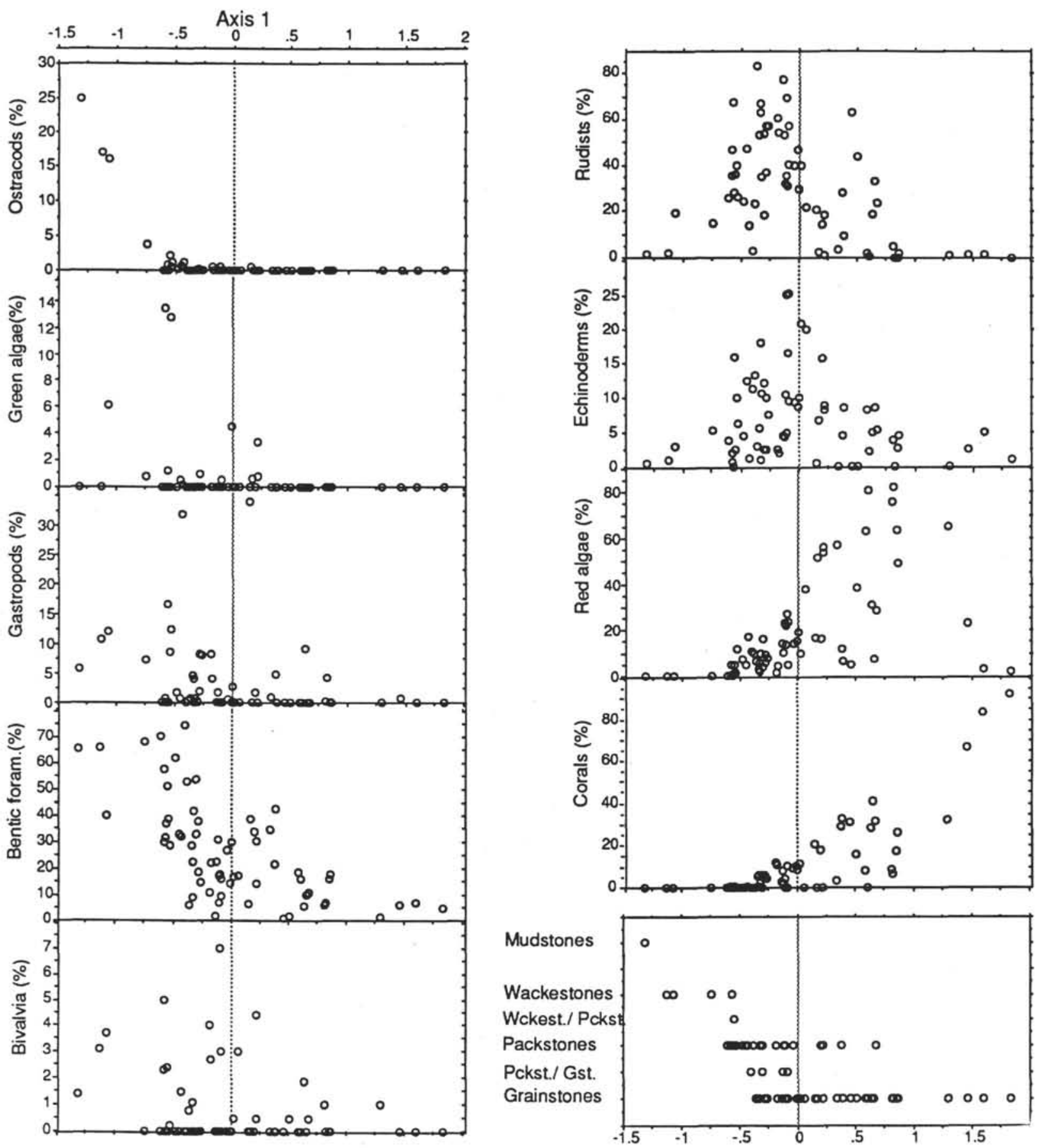

Figure 6. Typical relay (see Hennebert and Lees, 1991). Percentages of component grain types (variables) plotted vs. the relay index and limestone textures. Components are arranged in relay order.

are $1 \mathrm{~cm}$ in diameter (Distefanella mooretownensis [Trechmann], Distefanella sp.), apparently in life position, and may form small clusters of a few specimens (interval 144-874B-5R-1,32-44 cm). Red algae may encrust large skeletal pieces, thus forming small rhodoliths that range in size from 0.5 to $2 \mathrm{~cm}$ in diameter. Other grains include fragments of inocerames, corals (hexacorals and few octocorals), echinoids, gastropods, and green algae (dasycladaceans). Intraclasts consist of micritic elements with rudist and red algae, micrite with a few fragments of ostracodes, clotted laminated micrite, and elements of skeletal packstone.The porosity ranges from $1 \%$ to $10 \%$ in the packstone facies to $20 \%$ in the grainstone/rudstone facies and is moldic (in rudist and gastropod shells) to vuggy with solution-enlarged interparticle pores.
At Site 874 , boundstones are dominated by tabular coral colonies (hexacorals; octocorals: Polytremacis); a few stromatoporoids are locally reported. At Site 877 , rudists are very abundant throughout Subunit IIC and form the bulk of the organic frameworks. The rudist assemblage is successively dominated by clusters of small radiolitids (Distefanella mooretownensis [Trechmann], Distefanella sp.), which are usually $5-10 \mathrm{~mm}$ in diameter and $2-3 \mathrm{~cm}$ long in the lower part of Subunit IIC (47.6-105.7 mbsf), and then by loosely packed caprinid rudists (Mitrocaprina sp., Coralliochama orcutti White, Coralliochama sp., Plagioptychus aff. fragilis Chubb, P. aff. minor Chubb, Antillocaprina sp.), up to $6 \mathrm{~cm}$ in diameter, in its upper part. Other framework components include red algae (corallinaceans, peyssonneliaceans, and, to a lesser extent, solenoporaceans), which form 
either tightly packed various skeletal allochems in the associated sediment or encrustations, up to a few millimeters thick, on corals and/or rudists in association with encrusting foraminifers (Nubecularia) and microbial fabrics (Bacinella, Girvanella). Borings in framebuilding organisms are related to the activity of clionid sponges and worms. The abundance of algal bindstones composed of closely stacked red algal crusts (peyssonneliaceans and, to a lesser extent, corallinaceans) at the base of the subunit (interval 144-877-5R-3, 51-57 cm) suggests that these organisms may have played a role in the stabilization of previously mobile substrate, thus promoting larval attachment of frame builders and initiating framework development. Sediments associated to the boundstones consist of moderate to poorly sorted skeletal grainstone to packstone.

In the upper interval, the dominant facies include skeletal grainstone-rudstone with few algal-octocoral-rudist boundstone, which are apparently interlayered with, or enclosing, initially unconsolidated sediment. Boundstone intervals are seemingly more abundant at Site 877 than at Site 874. Downhole logging data show that, at Site 874, the lowest $2 \mathrm{~m}$ of Subunit IIA consists of very porous poorly cemented grainstone (4.3-6.5 mbsf), whereas the uppermost $4 \mathrm{~m}$ has a high weight-percent calcium-carbonate $(0.1-4.3 \mathrm{mbsf})$ and corresponds to cemented rudist-algal-stromatoporoid rudstone-boundstone facies. On the basis of well-log data at Site 874, the upper boundary of Subunit IIA should be placed at $6.5 \mathrm{mbsf}$ instead of at $11.1 \mathrm{mbsf}$, where it was initially placed by the Shipboard Scientific Party (1993a).

Skeletal grainstone and rudstone are generally poorly sorted, medium, coarse to very coarse grained, with various amounts of gravelsized fragments; a few packstone beds occur at Site 877. Major components include rudists (caprinids and radiolitids), corals (hexacorals and octocorals), calcareous sponges (chaetetids), and red algae (corallinaceans, peyssonneliaceans: Polystrata alba [Pfender], along with millimeter- to centimeter-sized bushes of solenoporaceans [Pycnoporidium] ) (Fig. 5 and Tables 3-4). Large skeletal fragments are usually micritized and display millimeter-sized borings. Benthic foraminifers (orbitoidids, rotaliids, and miliolids) are moderately abundant. Other grains are scarce and include echinoids, gastropods, green algae (a few fragments of Terquemella). Calcisphaerulids and small ammonites occur in trace abundance. Few intraclasts consist of micritic elements with rudist and algal fragments.

The boundstone includes encrusting laminar colonies of octocorals (Polytremacis) and hexacorals, rudists (radiolitids: Distefanella mooretownensis [Trechmann], Distefanella sp.; and caprinids: Mitrocaprina sp., Coralliochama orcutti White, Coralliochama sp., Plagioptychus aff. fragilis White, $P$. aff. minor White, Antillocaprina sp.), and red algal (solenoporaceans) clumps that are heavily encrusted $(0.3-1 \mathrm{~mm}$ average thickness) by red algae (corallinaceans and peyssonneliaceans: Polystrata alba [Pfender]) or, to a lesser extent, by foraminifers and microbial fabrics (Bacinella). The matrix is similar to the associated skeletal grainstone and rudstone.

\section{Interpretation}

Fossils and sedimentologic criteria suggest that the two "reef" units grew in a shallow-marine environment, probably less than 10$20 \mathrm{~m}$ deep. Associated bioclastic shoals acquire all sizes of debris from the carbonate factory by means of normal waves and storms, and pass some of the accumulation into the lagoonal zone during storms. Further evidence of turbulent waters includes the abrasion of shell fragments and the prevalence of grainstone and rudstone textures.

The frameworks are successively dominated by coralgal or rudist communities in the first "reef" episode and coralgal communities in the second "reef" episode. The abundance of grainstone intervals within the recovered cores and corresponding downhole logging signatures strongly suggests that the "rim" consisted of interbedded organic frameworks and shoals of wave-redeposited bioclastic grains. The rudist-coralgal framework probably was not composed of "waveresistant" structures, as shown by their weak organic frame; rather, it was probably restricted to a terrace-bench at the fair-weather wave base (ca. $10 \mathrm{~m}$ depth). In addition, the rigidity and stability of the framework must have been provided by early cementation (see "Diagenesis" section). Vertical zonation of rudist assemblages in the first "reef" episode may reflect either an evolutionary sequence in reef development or slight changes in environmental conditions. The development of a more open framework with loosely packed assemblages of recumbent large caprinid rudists may result from the smothering of the framework by increased sedimentation. Furthermore, the dominance of caprinid rudists over erect forms could be related to their better adaptability to high-energy environments and unstable substrates, such as shifting sands, where exposure of hard surfaces for attachment is likely to be limited in time and space (Skelton, 1979; Camoin et al., 1988). However, as noted by Kauffman and Sohl (1974) in the Caribbean, such recumbent rudists barely attained the gregarious habit. Relative to the coeval "reef" episode at Site 874, which includes algal-coral boundstone, the development of rudist communities at Site 877 suggests a lateral zonation of the framework, the rudist settlements being in a more lagoonward position with respect to the coral communities.

In contrast to the first "reef" unit, the second one does not display any clear lateral zonation, either because of the short duration of "reef" development or the late erosion processes.

\section{Lagoonal and Peritidal Deposits}

Site 874: Subunit IIB (Section 144-874B-2R-2 through Core 144-874B-4R, 11.1-38.1 mbsf); Site 877: Subunit IIB (Core 144-877A-2R through Core 144-877A-3R, 9.5-28.4 mbsf) (Fig. 4)

\section{Occurrence}

On the basis of well-log data at Site 874, the top of this lagoonaldominated lithologic Subunit IIB should be placed at the top surface of a well-cemented, 1-m-thick layer at $6.5 \mathrm{mbsf}$. This boundary assignment contrasts with the shipboard placement at $11.1 \mathrm{mbsf}$, because the interval from 11.1 to $6.5 \mathrm{mbsf}$ appears to be a continuation of the underlying cyclic facies, whereas $6.5 \mathrm{mbsf}$ is a major discontinuity. The lowest $10 \mathrm{~m}$ of Subunit IIB seemingly consists of two major sequences, similar in logging aspects to the underlying Subunit IIC.

\section{Description}

Typical facies consist of poorly sorted very pale brown to white skeletal grainstone, packstone to floatstone and light gray to pinkish gray burrowed dolomitic wackestones $(\mathrm{Pl}$. 1C). The contact between these two facies usually corresponds to an unconformity with borings, local erosion, and reworking of intraclasts, implying early lithification processes (interval 144-877A-1R-1, 124-128 cm). Radiolitid clusters (Distefanella mooretownensis [Trechmann]) are reported in interval 144-874B-3R-3, $0-18 \mathrm{~cm}$. The signature on the FMS is characterized by beds of high resistivity (skeletal packstones to floatstone) alternating with beds of low resistivity (lagoonal foraminiferwackestone to -packstone with leached gastropod molds).

Major components of skeletal packstone to floatstone include micritized fragments of usually leached gastropods, rudist fragments (radiolitids and scarce caprinids), inoceramids, and other bivalves (probable pycnodonts) (Fig. 5 and Tables 3-4). Benthic foraminifers include miliolids, rotaliids, discorbids, and, to a lesser extent, orbitoidids, lituolids, and encrusting forms on large bioclasts. Other grains are clearly subordinate, including (in order of decreasing abundance) fragments of green algae (dasycladaceans: Terquemella), red algae (corallinaceans and peyssonneliaceans), corals (hexacorals and octocorals), and echinoids. Calcisphaerulids and planktonic foraminifers (Rugoglobigerina sp.) occur in trace abundance. The micritic matrix is locally peloidal and may display a geopetal distribution in intergranular pores. Average grain sizes are $0.5-2 \mathrm{~mm}$ and up to $1 \mathrm{~cm}$ in floatstone beds. 
Dolomitic wackestone beds are characterized by abundant fenestrae, which may form irregular networks of vertically elongated tiny canalicules reminiscent of fluid escape structures or horizontal stacked alignments ("Laminoid Fenestral Fabric" sensu Tebbutt et al., 1965). The micritic matrix is brownish and may display locally a reticulate aspect. The skeletal content is poor and limited to small gastropods (cerithids), benthic foraminifers (miliolid, discorbids, textulariids, fragments of Dicyclina and orbitoidids), smooth-shelled ostracodes, green algae (Terquemella), and a few abraded fragments of corals, red algae, and rudists. These wackestones may display undulating laminations, probably microbial in origin, which are commonly cut irregularly because of burrowing (common millimeter-sized tubes), loading, and/or fluid escape.

\section{Interpretation}

A shallow-marine depositional environment, probably a few meters deep, may be inferred from the fossil content and the sedimentologic criteria detailed in the foraminifer-gastropod wackestone. Among these criteria, the fine-grained matrix and the scarcity, or even the lack, of conventional current indicators imply quiet-water conditions. The occurrence of laminar microbial mats and the abundance of fenestrae are consistent with very shallow depths. Temporary periods of emergence may be deduced from the early dolomitization of wackestone beds, the early dissolution processes of shells, and the local reworking of caliche lithoclasts. The local prevalence of paucispecific assemblages of very small foraminifers, smooth-shelled ostracodes, and gastropods (cerithids) may indicate temporary episodes of restriction and rather unfavorable ecologic conditions such as low illumination or oxygenation, temperature fluctuations, poor nutrient availability, or turbidity.

Skeletal packstone and floatstone with abraded bioclasts interlayered with wackestone beds correspond to redeposited "washovers" or "storm beds" from the outer debris shoals caused by periodical storms, changes in current patterns, or short-term relative sealevel fluctuations.

\section{Diagenesis}

Sediments on guyots generally display a complex diagenetic history involving carbonate cementation, transformation of carbonate phases, dissolution processes, cavity fillings, phosphatization, and secondary mobilization of Fe-Mn oxides. The data presented herein represent an overview of the diagenetic features reported in sediments from the inner perimeter ridge of Wodejebato Guyot to record the successive changes of physicochemical conditions controlling diagenesis.

\section{Porosity and Cementation}

The sediments from the guyots still exhibit a high percentage of porosity in contrast to carbonates influenced by burial diagenesis. On Wodejebato Guyot, sediments are strongly cemented in the upper 40 $\mathrm{m}$ of the carbonate sequence (Subunits IIA and IIB, and the top of Subunit IIC), with a clear diagenetic boundary occurring in Cores 144-874B-5R and 144-877A-5R, coeval with a sharp increase in porosity around 65 mbsf downward caused by poor cementation in the underlying units. In skeletal shoal facies, intense leaching of the original grains resulted in high moldic, vuggy, and solution-enlarged interparticle porosity, ranging from $30 \%$ to $40 \%$. These sediments are generally poorly lithified, although isopachous crusts of equant calcite cements may line intra- and interskeletal voids. In contrast, porosity generally ranges from $1 \%$ to $10 \%$ in the upper part of the carbonate sequence because of extensive cementation by multiple generations of banded calcitic cements, up to a few millimeters thick. The remaining pores are intragranular, moldic (especially in lagoonal beds), and sheltered, with a few solution-enlarged, intra- and interparticle pores. Additional fenestral porosity is present in peritidal carbonate beds.
In the upper part of the carbonate sequence, the general diagenetic sequence within inter- and intragranular pores includes the following:

1. Isopachous fringes of amber to brownish bladed, radiaxial to fascicular-optic calcites that exhibit a typical sweeping extinction and include equant, bladed, and fibrous morphologies. These calcites appear to be zoned by variations of inclusion density, with the outermost zone being generally clear (i.e., inclusion poor; Plates $2-3$ ). The crystals generally thicken away from cavity walls; boundaries between adjacent crystals are sharp. These cements may display a botryoidal habit in large intergranular cavities. These cements partly fill syndepositional primary porosity and are completely absent in secondary pores, especially moldic pores.

2. Prismatic to scalenohedral, inclusion-free calcites overgrowing radiaxial to fascicular-optic calcites (Plates $2 \mathrm{~B}$ and $3 \mathrm{~A}-\mathrm{B}$ ). The contact between these clear calcites and inclusion-rich, bladed, radiaxial to fascicular-optic calcites mimics crystal terminations.

3. Translucent scalenohedral to equant blocky calcite cements. These cements may crosscut the isopachous fringes of fascicularoptic calcitic cements (Plates $2 \mathrm{~B}$ and $3 \mathrm{C}-\mathrm{D}$ ). Equant blocky calcite cements also fill the chambers of foraminifers and cavities in the overlying Eocene pelagic cap.

Although calcite cements generally attest the phreatic nature of the diagenetic environment, petrographic features alone are not conclusive as diagenetic indicators, and it is of prime importance to integrate also geochemical approaches. However, the present isotopic compositions of carbonate cements reflect a mixture of the original composition of carbonate cements and late diagenetic products. The stable carbon and oxygen isotopic compositions of the successive cement phases are plotted in Figure 7.

Radiaxial and fascicular-optic calcites are generally interpreted as resulting from the lateral coalescence of previous radial fibrous cements (Kendall, 1977), either aragonitic (Bathurst, 1977) or high Mg-calcite (Lohmann and Meyers, 1977), or from direct precipitation (Sandberg, 1985; Kendall, 1985). The stable isotope composition (carbon and oxygen) of Wodejebato radiaxial and fascicular optic calcites ranges, respectively, from $+1.81 \%$ to $+3.03 \%$ PDB (average: $+2.34 \%$ ) for $\delta^{13} \mathrm{C}$ and from $-1.46 \%$ to $-0.34 \%$ PDB (average $-0.83 \%$ ) for $\delta^{18} \mathrm{O}$. These values are slightly lighter than other modern marine cements, including high $\mathrm{Mg}$-calcite cements from Pikinni (Gonzalez and Lohmann, 1985). Stable carbon isotope compositions are within the theoretical field of $\delta^{13} \mathrm{C}$ values for calcite precipitated from modern Pacific seawater (i.e., $+2.0 \%$ to $+2.5 \%$ PDB Kroopnick et al., 1977). Thus, petrographic observations and stable isotope data support a precipitation penecontemporaneous with deposition in a shallow-marine environment. Stable carbon and oxygen isotope values presented herein are similar to those reported from radiaxial and fascicular-optic calcite cements in the Bahama Escarpment (Freeman-Lynde et al., 1986) and comparable to those occurring in the Miocene of Anewetak Atoll (Saller, 1986). In contrast, they are slightly higher than those measured on Early Cretaceous radiaxial calcites from Mexico (Moldovanyi and Lohman, 1984).

The $\delta^{13} \mathrm{C}$ and $\delta^{18} \mathrm{O}$ values measured in clear, inclusion-free, scalenohedral calcites range, respectively, from $+1.85 \%$ to $+2.63 \%$ PDB (average: $+2.22 \%$ PDB) and from $-1.56 \%$ to $+0.07 \%$ PDB (average: $-1.03 \%$ PDB). Average $\delta^{13} \mathrm{C}$ and $\delta^{18} \mathrm{O}$ values measured on blocky calcites are, respectively, $+1.46 \%$ and $-1.62 \%$ PDB. Despite partial overlap between these data and those reported on bladed, radiaxial, and fascicular optic calcites, the shift between values measured on these two types of cements is slight, ranging from $0.1 \%$ to $0.8 \%$ for $\delta^{13} \mathrm{C}$ and from $0.2 \%$ to $0.8 \%$ for $\delta^{18} \mathrm{O}$. Carbon isotope values for these cements are slightly lighter than most modern shallow-marine cements (see Gonzalez and Lohmann, 1985), suggesting precipitation in relatively deep-marine waters where the $\delta^{13} \mathrm{C}$ of marine bicarbonate is $1 \%$ to $2 \%$ lighter than in surface-marine waters (Kroopnick et al., 
LOWER "REEF" UNIT
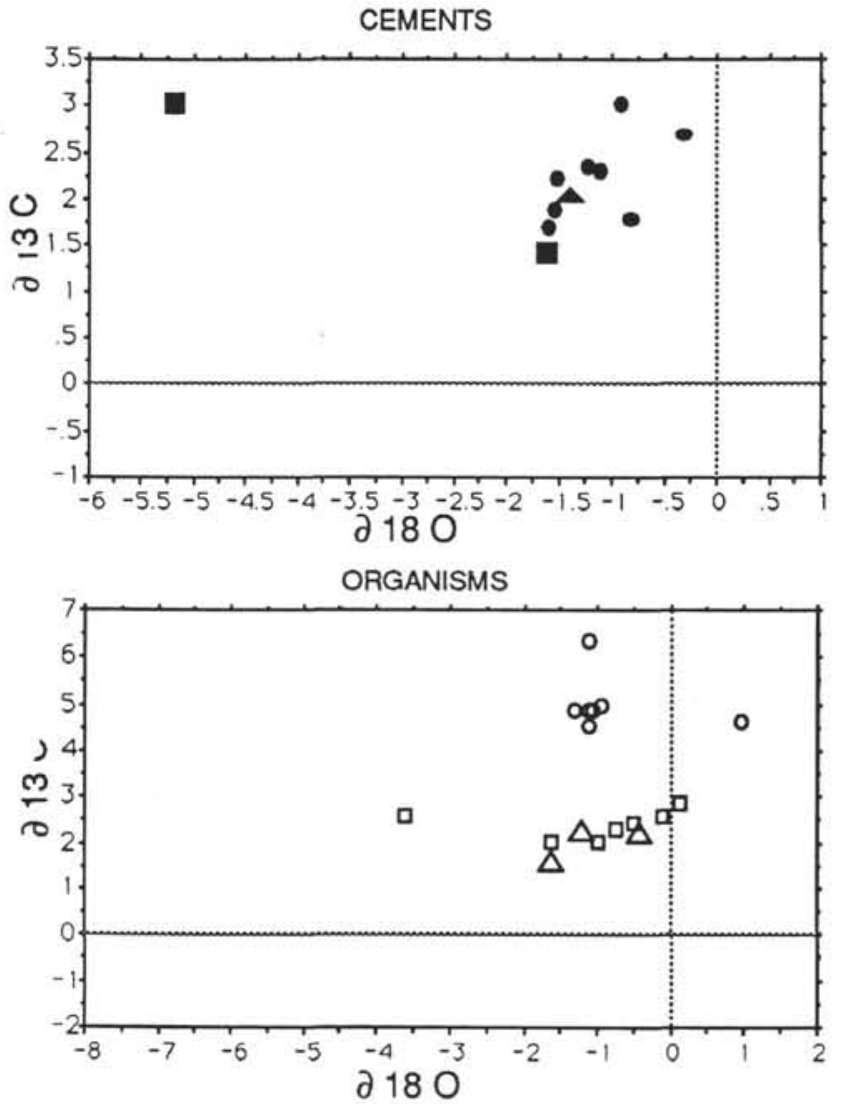

UPPER "REEF" UNIT
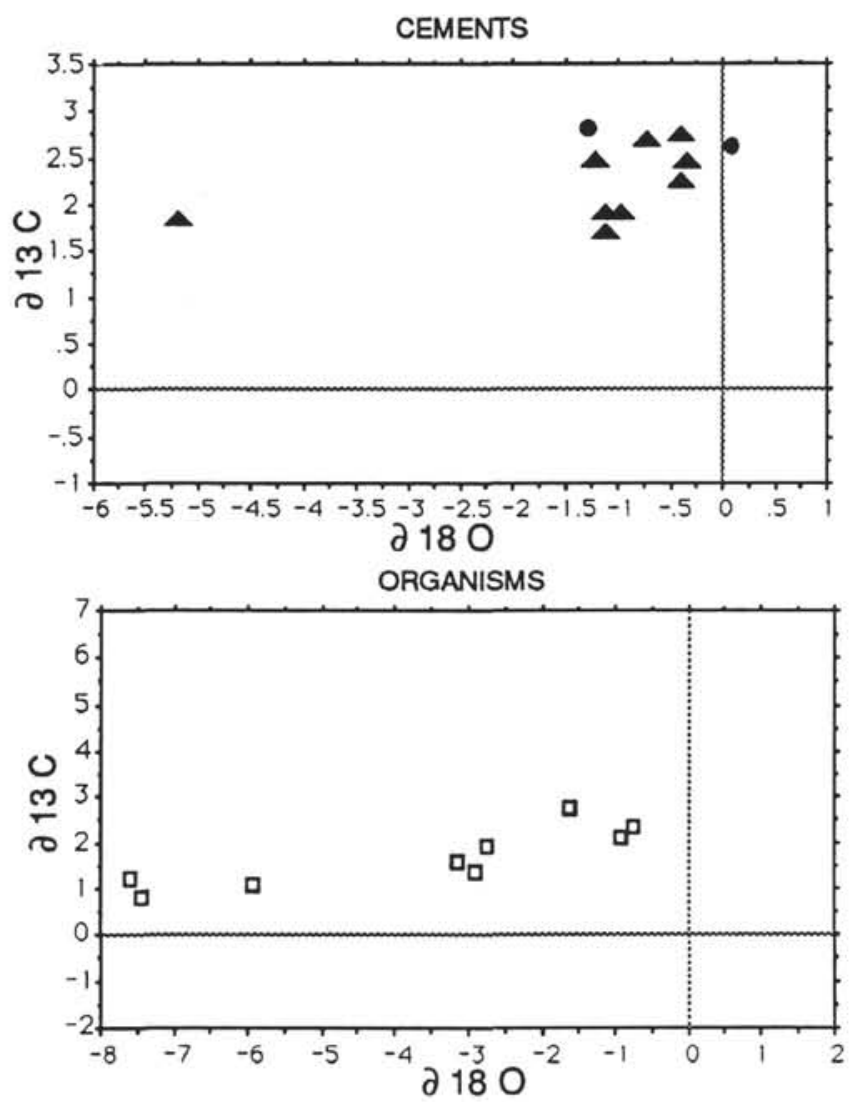

Figure 7. Stable carbon and oxygen isotopic composition of successive cement phases and skeletal components in the two "reef" units at Sites 874 and 877 (left column $=$ lower unit, and right column $=$ upper unit). Cements: black circles $=$ scalenohedral calcite, black squares $=$ clear equant spars, and black triangles $=$ radiaxial to fascicular-optic calcite cements. Skeletal components: open circles $=$ aragonitic rudist shells, open squares $=$ calcite replacing originally aragonitic layers with relict microstructures in rudist shells, and open triangles = calcite replacing originally aragonitic layers without relict microstructures in rudist shells.

1977). Blocky and scalenohedral calcite cements produced in a phreatic meteoric environment should have lighter $\delta^{13} \mathrm{C}$ and $\delta^{18} \mathrm{O}$ compositions. Cements precipitated from cold deep waters are calcite without appreciable magnesium (Schlager and James, 1978; Hine and Steinmetz, 1984). The stable carbon and oxygen compositions are similar to those reported from cements of the same type in Maastrichtian deposits from the Bahama Escarpment (Freeman-Lynde et al., 1986) and other Caribbean areas (DSDP Leg 15; Anderson and Schneidermann, 1973). In contrast, values reported from Wodejebato calcite cements are lighter than those reported in coarse crystalline calcite cements $\left(\delta^{18} \mathrm{O}=+3 \%\right.$; $\delta^{13} \mathrm{C}=+2.5 \%$ ) from Limalok (formerly Harrie) Guyot by Lincoln (1990), suggesting precipitation in warmer waters than on Limalok Guyot.

\section{Skeletal Diagenesis}

Former aragonitic skeletons or parts of skeletons (corals, rudists and gastropods) may exhibit a differential preservation throughout the carbonate sequence. Coral and gastropod skeletons are either totally replaced by blocky calcite or dissolved and preserved only as micritic envelopes. Such a fragile pore network could only have been developed by dissolution in situ, either by meteoric waters or by deepmarine waters undersaturated with respect to aragonite. The general lack of internal sediment and meteoric cements, filling moldic pores, suggests that the aragonite dissolution probably occurred away from the rock-water interface. Modern Pacific Ocean water is undersaturated with respect to aragonite at depths below 300-350 m (Scholle et al., 1983; Saller, 1986) resulting in dissolution of aragonite and high $\mathrm{Mg}$-calcite. Similar sequences of aragonite dissolution and subsequent calcite precipitation by marine waters undersaturated with respect to aragonite have been reported in Jamaica (Land and Moore, 1980), in the Bahamas Escarpment (Freeman-Lynde et al., 1986), and on other Pacific seamounts (Haggerty, 1982). These processes have been described as "subsolution" in the Calcareous Alps (Schlager, 1974) and are obviously related to the duration of nonsedimentation.

In some intervals, rudist and inoceramid shells or parts of shells display a gradational sequence of transformation, from fragments totally replaced by clear, inclusion-free, blocky calcites (Plates 4A, $4 B$, and $4 D$ ) to fully preserved aragonitic parts of shells (e.g., interval $144-877$ A-5R-3, 103-109 cm) through the partial recrystallization where relics of aragonitic skeletal structures are preserved in inclusion-rich, coarse, blocky calcite cements. In the latter case, the limits of calcite crystals may crosscut both the initial aragonitic structures and the bladed to fibrous cements that fill the intragranular pores (Plate 4C). The stable carbon and oxygen isotope compositions of the rudist shells are plotted in Figure 7.

The stable carbon and oxygen compositions of well-preserved aragonitic rudists $(60 \%-100 \%$ aragonite) range, respectively, from $4.53 \%$ to $6.35 \%$ PDB (average $5.08 \%$ PDB) for $\delta^{13} \mathrm{C}$ and from $-1.32 \%$ to $-0.94 \%$ PDB (average $-1.115 \%$ PDB) for $\delta^{18} \mathrm{O}$. These values are similar to the stable isotopic composition of aragonitic rudists such as Antillocaprina and Plagioptychus (Al-Aasm and Veizer, 1986). As the diagenetic changes are very slight, these values probably reflect the isotopic values of initial seawater. 
Isotopic values obtained in inclusion-rich calcites exhibiting relics of aragonitic skeletal structures range, respectively, from $+2.05 \%$ to $+2.78 \%$ PDB (average $+2.46 \%$ PDB) for $\delta^{13} \mathrm{C}$ and from $-1.01 \%$ to $-0.07 \%$ PDB (average $-0.484 \%$ PDB) for $\delta^{18} \mathrm{O}$. These values are very close to those obtained on similar neomorphic calcites by $\mathrm{Al}-$ Aasm and Veizer (1986). With respect to values measured on aragonitic shells or fragments of shells, only a slight shift occurs in $\delta^{18} \mathrm{O}$, whereas the decrease in $\delta^{13} \mathrm{C}$ is sharper. This suggests that the $\delta^{18} \mathrm{O}$ and the temperature of diagenetic water did not vary much from that of the coeval seawater during an early stage of diagenesis, implying the wet replacement of aragonitic components.

Isotopic values obtained in inclusion-free calcites exhibiting few or no relics of aragonitic skeletal structures range, respectively, from $+1.15 \%$ to $+1.3 \%$ PDB (average $+1.21 \%$ PDB) for $\delta^{13} \mathrm{C}$ and from $-7.64 \%$ to $-5.95 \%$ PDB (average $-7.06 \%$ PDB) for $\delta^{18} \mathrm{O}$. The isotopic shift, especially in $\delta^{13} \mathrm{C}$ confirms solution-reprecipitation processes, implying a greater alteration at a later diagenetic stage. The aragonite-calcite replacements may have occurred in waters that were depleted in ${ }^{18} \mathrm{O}$ compared to depositional waters, possibly in meteoric waters, as noted by Sandberg and Hudson (1983) and Al Aasm and Veizer (1986), for the calcitization of aragonitic bivalve shells. These transformations were only noted at the top of the carbonate sequence at Site 874 .

\section{Dolomitization}

A few dolomitic beds were reported in lagoonal facies from Subunit IIB (interval 144-874B-2R-2, 47-55 cm); these correspond to the faint dolomitization of gastropod-foraminifer wackestone. The lack of any dolomitization in the overlying and underlying intervals suggests that early dolomitization processes should be related to temporary and local emergence.

\section{Dissolution Processes and Cavity Fillings}

Dissolution may affect formerly aragonitic shells (e.g., gastropods, caprinid rudists, corals) and encasing sediments, thus creating both moldic pores and solution cavities, which are either still open or filled by cements and/or internal sediments. Relative timing of the involved dissolution processes can be determined precisely with respect to the ages of sediment fillings.

Yellowish, reddish, or rusty brown internal sediment displaying a geopetal pattern may fill partly moldic pores; it consists of micrite with scarce, smooth-shelled ostracodes and very small benthic foraminifers. This implies dissolution of rudist and gastropod shells, followed by sediment infilling of the moldic pores. The same type of internal micritic sediments may partly fill irregular solution cavities, up to $1 \mathrm{~cm}$ in size, which occur especially in lagoonal deposits and underlying "reef" facies. In this case, the internal micritic sediments postdate successive generations of banded isopachous crusts of radiaxial and fascicular-optic calcite cements. This implies a dissolution during an early stage of diagenesis. The remaining moldic porosity is usually occluded by scalenohedral and blocky calcite cements. Early meteoric diagenetic processes are indicated also by the postdating of equant, blocky, calcite cements by fibrous and bladed calcites in lagoonal beds.

Late fillings of centimeter-sized solution cavities in the platform carbonates consist of white to orange-brown micritic internal sediments corresponding to mudstone and wackestone rich in pelagic organisms associated with micritized and phosphatized fragments of benthic foraminifers and rudists (radiolitids). The biostratigraphic data show that the filling seems to be an episodic process. Planktonic foraminifers and calcareous nannofossils constitute distinctive assemblages, ranging in age from the middle Maastrichtian (interval 144874B-3R-1, 114-118 cm, and between intervals 144-877A-1R-1, 3-24 $\mathrm{cm}$, and $-3 \mathrm{R}-1,92-97 \mathrm{~cm}$ ), to the middle Eocene (interval 144-877A$1 \mathrm{R}-2,0-37 \mathrm{~cm}$ ), through the late Paleocene and the early Eocene (intervals 144-874B-1R-1, 47-50 cm, and -3R-1, 114-118 cm, and intervals 144-877A-1R-1, 3-24 cm, to -3R-1, 92-97 cm) (Shipboard Scientific Party, 1993a, 1993b). This implies that the drowning of the carbonate platform occurred during the Maastrichtian and that pelagic sedimentation lasted until the middle Eocene, even if no early Paleocene sediments were recovered. Phosphate and manganese grains and phosphate staining occur within these pelagic sediments. The deepest occurrence of pelagic sediments within platform carbonates is recorded in interval 144-874B-6R-1, 0-4 cm, about $50 \mathrm{~m}$ beneath the top of the carbonate sequence. The mechanism involved in the formation of these cavities cannot be deciphered because of the uncertainties concerning their morphologies, widths, and relationships with encasing shallow-water carbonates. These cavities could correspond either to narrow fractures affecting the carbonate cap or to larger cavities possibly related to karstification processes.

\section{POST-DROWNING FACIES}

The platform limestone sequence is topped by a complex series of phosphate-manganese dense black crusts (Plate 1D), up to $3 \mathrm{~cm}$ thick, sealing well-cemented, foraminifer-rudist grainstone and manganesephosphate-coated limestone conglomerate. The upper few centimeters of these limestones are recrystallized and red stained by phosphate, which may coat skeletal grains. Manganese dendrites and threads grow inward, suggesting a secondary mobilization caused by the good solubility of the Fe-Mn oxides. The contact surface between the platform carbonates and the manganese-phosphate crust is scalloped and displays multiple generations of borings, ranging in size from 20 to $2 \mathrm{~mm}$. The crust includes multiple generations of stacked digitate and laminated accretions embedding clasts both of foraminifer rudist grainstone, $2-3 \mathrm{~mm}$ in size, and late Paleocene pelagic limestone. The crusts grew probably during periods of low or no sedimentation and have been mechanically reworked several times. The production of clasts included in the crusts is seemingly related to the intense boring activity and to erosion and redeposition, probably because of bottom-water activity, during Eocene time. Pores between the manganese accretions are filled with several generations of pelagic sediments rich in planktonic foraminifers and nannofossils, late Paleocene to middle Eocene in age, implying a deep-marine depositional environment (i.e., tens to hundreds of meters) and very slow accretion rates. These sediments are similar to those infilling the irregularly shaped solution cavities within shallow-water carbonates.

As noted by Grötsch and Flügel (1992), the geologic setting and time relations leading to phosphatization processes recorded at the top of the guyots are clearer than for phosphate deposits formed in regions subjected to coastal upwelling. Because the amount of phosphate in the Central Pacific photic zone is almost nil, the upwelling of deep water or exposure to it is the only available source for phosphate (Grötsch and Flügel, 1992). A combination of winnowing and physical and biological erosion, together with the continuous process of mineralization and dissolution, results in concentrations of phosphate on the hardgrounds (Baturin, 1971; Jarvis, 1980; Föllmi, 1989; Grötsch and Flügel, 1992). The microbial role, especially sulfato-reducing bacteria (Williams, 1984), in phosphogenesis has been reported in similar seamount phosphorites of the Central Pacific by Rao and Burnett (1990) and on Cretaceous pelagic highs from the Helvetic Domain (Delamette, 1988). Phosphatization may have started after drowning when the guyot entered the oxygen-minimum zone (see Burnett et al., 1980, for Albian counterparts), thus favoring microbial "blooms." Furthermore, paleoceanographic events that promote productivity and intensification and expansion of the oxygen-minimum zone should produce crusts with increased amounts of $\mathrm{Mn}$ and manganophile elements (Hein et al., 1992). Another interpretation could rely on the intensification of upwelling, because Wodejebato Guyot was probably located in the area of the central equatorial upwelling at the end of the carbonate platform development. 


\section{ATOLL GENESIS AND DEPOSITIONAL HISTORY}

\section{Flooding of the Volcanic Substrate}

The depositional history of the inner perimeter ridge of Wodejebato Guyot began with the end of volcanism before or during Campanian time (78-83 Ma; Pringle et al., this volume). As other midoceanic platforms, this guyot initially consisted of a broad shield volcano. The dusky red to gray clay and claystone, which form the bulk of Unit III at Sites 874 and 877, are a subaerial weathering profile of the basalt as shown by the preservation of vesicular texture, including laths of plagioclase and vesicles filled by white patches of zeolites in these flows. The contact between the basalt and the clay is gradational and the degree of alteration decreases downward. The duration of subaerial exposure required for the formation of such a $15-\mathrm{m}$-thick weathering profile is consistent with the radiometric ages obtained on lavas and with the biostratigraphic data obtained from the overlying marine deposits. With subsidence and coeval erosion, the summit of the shield volcano was truncated, creating topographic depressions filled with clay-rich sediments produced by pedogenetic processes. At this time, a clearly defined lowstand systems tract (LST) of slope fans and a prograding slope wedge were lacking on these platforms because the flanks of the volcano were sufficiently steep to bypass sediment directly to the adjacent deep ocean basin.

The initial overlying marine deposits, dated late Campanian (Premoli Silva, Haggerty, Rack, et al., 1993), correspond to black organic-rich clay containing marine and continental material (e.g., calcareous nannofossils and preserved kerogen-type woody material) deposited in a quiet, reducing, shallow-marine environment (see Buchardt et al., this volume). The basal limestone recovered from above the clay consists of a grainstone that includes fauna and flora (larger foraminifers, coral fragments, and red algae) typical of a shallow-marine environment with an open circulation. The partial preservation of the weathering profile and overlying marine clays, and the lack of any clay reworking at the base of the carbonate sequence of Unit II, are consistent with a slow rise in sea level and rapid burial.

\section{Development of the Carbonate Platform}

The development of the carbonate platform was clearly governed both by the growth potential of the carbonate systems and by relative sea-level fluctuations, corresponding to a balance between thermal subsidence rates averaging $25 \mathrm{~m} / \mathrm{m}$.y. (see Detrick and Crough, 1978 for thermally rejuvenated lithosphere) and eustatic sea-level changes.

A two-stage transgression initiated the carbonate platform on a gently inclined volcanic island shallowing toward a central substrate high. This transgression is clearly correlated with a two-step development of the carbonate platform. The Holocene transgressive model of a "barrier-island complex" moving landward over a sheltered "estuary" has some similarities to the landward movement of an algalcoral-grainstone shoal over an organic-rich nearshore marsh underlying the base of the carbonate sequence occurring at Sites 874 and 877 . The overall vertical evolution of platform carbonates corresponds to an upward-shallowing sequence, as shown by the relays detected by means of correspondence analyses conducted on skeletal components (Figs. 5-6; see also Hennebert and Lees, 1991).

The environmental gradient is obvious in Sites 874 and 877 where an arch effect, the so-called "Guttman effect," appears (lower part of Fig. 5). Evolution of biological components fits with a relay effect, especially at Sites 874 and 877 . These relays might be characterized by a progressive and continuous shift of the organisms in time and space, related to hydrodynamism and confinement.

Some of the major successions at Site 874 consist of a series of 6-mthick, upward-shallowing sequences. The 6 -m-thick sequences at Site 874 are similar in general aspect and thickness to the cycles observed on other guyots drilled during Leg 143 (P. Cooper, pers. comm., 1993). These parasequences were interpreted as 100,000-yr, Milankovitchdriven, sea-level fluctuations (P. Cooper, pers. comm., 1993).
Sequence types are closely related to sea-level fluctuations that induced variations of accommodation with subsequent shift from rhythmic sequences when the ridge was near sea level (i.e., during the late part of highstand systems tracts [HST] or at the base of transgressive systems tracts [TST]), to cyclic sequences when sea level was high and accommodation was at a maximum.

The first phase of carbonate platform development corresponds to the accumulation of skeletal sand piles edging a still-emerged volcanic relief, near the shelf margin (Fig. 8). They accumulated in a shallow-marine depositional environment with a sedimentary regime dominated by currents. The initial buildups correspond to the early stages of a transgressive systems tract (TST); their formation probably occurred during a time when sea level was low or when the carbonate factory kept pace with a slow rise in sea level.

The overlying sequence corresponds to a series of stacked retrogradational sand shoal units with reflectors truncating against the volcanic substrate reflector (Fig. 8). This backstepping onto the gentle slope of the volcanic rocks implies that the carbonate factory failed to keep up with a rapid rise in sea level and spread landward. This implies that these sand shoal units still belong to a TST. A maximum flooding surface is tentatively assigned at about $152.5 \mathrm{mbsf}$, where the maximum peak of natural gamma-ray intensity is interpreted as the development of maximum algal encrustation (Fig. 3). An upward shallowing in depositional depth is suggested, but no well-defined upward-shallowing cycles could be identified.

The stabilization of sea level induced the progradation of sand shoal units toward the shelf margin, characterizing the beginning of an HST (Fig. 8C-D). However, short-term backstepping or aggradation and progradation may have been induced by minor sea-level changes (see Arnaud Vanneau et al., this volume). At this time, the central volcanic high was still emerged and exposed to weathering processes.

The bulk of sand shoal units seemingly corresponds to an LST deposited near the edge of the summit plateau after a seaward migration of the carbonate factory; at this time, carbonate production was minimal. The partial sediment starvation of this debris apron may have caused enrichment of iron oxides and the reddish coloration of the grainstone. The occurrence of weathering processes was not supported by microfacies (no vadose-type cement), or by isotopes (no vadose signature), or by chemistry (no thorium or silica/aluminum increase suggesting soil clays).

A subsequent rise in sea level is responsible for backstepping toward the center of the plateau of the overlying carbonate sequence, including first sand shoal units and then early cemented rudist-coralgal frameworks facing the open sea, with a grainstone shoal accumulation on its lagoonward edge. This sequence corresponds to the second step of carbonate platform development (Fig. 8) and was deposited in a shallow-marine environment. Coevally, the central volcanic high was flooded and covered by sand shoal facies similar to those reported at the base of the carbonate sequence from the inner perimeter ridge (Arnaud Vanneau et al., this volume). This flooding induced changes in the dominant stratal pattern of the TST and the HST: from retrogradational and progradational to aggradational. As sea level stabilized, the rudist coralgal units began to aggrade and then prograde. At this stage of development, the relief of the inner perimeter ridge was accentuated, probably on the order of $36 \mathrm{~m}$ above the coeval lagoonal sediments, and the carbonate platform was therefore forming an atolllike structure (Arnaud Vanneau et al., 1993). The more pronounced relief of the perimeter ridges on the northeastern flank of the guyot suggests that prevailing wind and wave activity occurred in this zone.

The continued seaward progradation of reef units induced the shift of depositional setting and the lagoonal deposits invaded the inner perimeter ridge, forming the upper part of the HST. The seaward migration of lagoonal deposits resulted in the complete filling-up of the back-reef area and the leveling of the carbonate platform topography. The prolonged sea-level stand, or the lowering of sea level, may have induced local and temporary subaerial exposures by means of the dissolution of lagoonal beds and, possibly, dolomitization processes. 

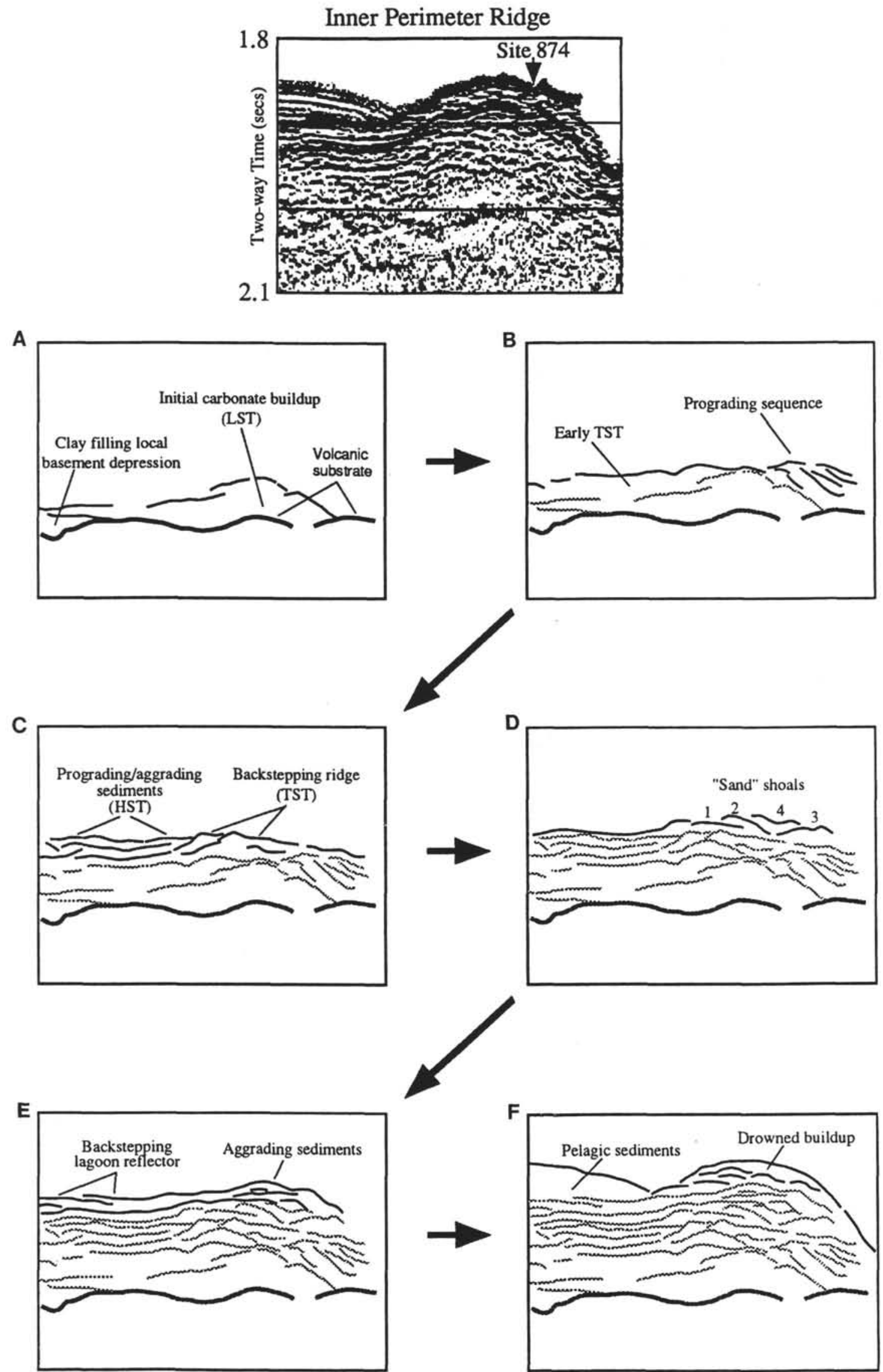

Figure 8. Correlations between reflectors occurring in the carbonate sequence and successive systems tracts, from the initiation of the carbonate platform (A) to the final drowning $(\mathbf{F})$. 
However, no meteoric cementation has been observed in the recovered intervals. The weak downward penetration of dolomitizing fluids suggests a limited fall in seawater and water table levels, implying juvenile karstification processes. Such a short emergence near the top of a carbonate sequence is a common feature reported on Type A guyots (see Winterer and Metzler, 1984; McNutt et al., 1990) and other platforms (Erlich et al., 1990). The duration of emergence is usually estimated to be on the order of $100 \mathrm{k.y}$., which is consistent with the data reported from Wodejebato Guyot.

The next transgression caused backstepping of the carbonate factory toward the lagoon, forming a TST. This rapid transgression and lagoonward shift of depositional environments initially caused the accumulation of wave-reworked grainstone from the coral-algal belt, followed by temporary establishment of rudist-coralgal frameworks onto the backstepped grainstone. The lack of any lateral zonation in these organic frameworks should be related to the short duration of this "reef" unit. The sequence, involving a barrier-reef growth after short-term emergence, is similar to those reported on Type A guyots (see Winterer and Metzler, 1984; McNutt et al., 1990) and other platforms (Erlich et al., 1990).

\section{Demise and Drowning of the Carbonate Platform}

The solution cavities filled by pelagic sediments that occur as deep as $50 \mathrm{~m}$ in the platform carbonates may have been formed by the enlargement of fractures in a deep-marine environment or, more probably, by karstification as indicated by the timing and the nature of the cavity system. The thorough penetration of platform carbonates by these vertical cavities indicates exposure of the top of the formation. The creation of such deep cavities during the juvenile karstification recorded at the top of lagoonal beds is unlikely because of its shortness.

The morphology of the drowned atoll (i.e., hummocky upper surface of platform carbonates) recorded on seismic lines suggests that karstification processes were in motion before the final drowning. Furthermore, there seems to be no mechanism for marine erosion to have produced the trough separating the inner perimeter ridge from the outer one (Enos et al., this volume). If subaerial exposure has produced the trough, a minimum lowering of $90 \mathrm{~m}$ is required, as shown by the relief between the top of the inner ridge and the floor of the trough; this trough would therefore correspond to a large doline parallel to adjacent slope (Enos et al., this volume). However, the only isotopic evidence of the occurrence of meteoric waters relies on the stable carbon and oxygen values of some neomorphosed rudists at the top of the inner ridge (see Fig. 7). All the cements analyzed in the upper "reef" unit display a marine isotopic signature (see Fig. 7). The formation of 50-mdeep cavity systems in the platform carbonates and the topography of the upper surface of platform carbonates through karstification processes would imply an emergence of about $1 \mathrm{~m} . \mathrm{y}$. (see Montaggioni and Camoin, in press, for Miocene atoll counterparts). During such an emergence, karstification processes should have removed partly the top of the carbonate sequence at Wodejebato Guyot, based on an average dissolution rate of $35 \mathrm{~m} / \mathrm{m} . \mathrm{y}$. (Lincoln and Schlanger, 1987). This could explain the lack of pre-drowning lagoonal beds, which could be related to a regression in the late stage of carbonate platform development.

The occurrence of Maastrichtian pelagic sediments as cavity fillings implies a rapid sea-level rise of a few tens of meters during Maastrichtian time, just after exposure. The association of planktonic foraminifers with Gansserina wiedenmayeri (see Premoli Silva et al., this volume) confines the age of the formation and the infilling of cavities to a time span ranging from the $G$. gansseri Zone to the lower part of the A. mayaorensis Zone (Fig. 9). The data suggest a shortterm regressive-transgressive cycle with a high amplitude in the late Maastrichtian ( $G$. gansseri Zone) that is consistent with sea-level changes with an amplitude of $100 \mathrm{~m}$ at the top of the Supercycle UZA-4 (Haq et al., 1987) (Fig. 9). This sequence of events, which implies a strong fall in sea level, leading to karstification before an even more rapid rise of greater amplitude, and ultimately causing drowning, is similar to the process found in the Early Cretaceous atoll reefs described by Grötsch and Flügel (1992).

The complete shutdown of platform carbonate production during re-flooding cannot be explained only by the rise of sea level because subsidence rates and long-term sea-level changes are at least 1 order of magnitude lower than the potential growth rates of carbonate platforms (Schlager, 1981). We assume that benthic growth was reduced, or even hampered, by the deterioration of environmental conditions, which appear as a cause of abrupt platform drowning (Schlager, 1981). Furthermore, because of their size, small platforms are more susceptible to drowning events that can place them out of the photic zone and effectively shut down the shallow-water "carbonate factory" (see Dominguez et al., 1988, for Holocene counterparts).

Strong but short perturbations of climatic equilibrium may explain rapid sea-level changes and environmental deterioration that could have removed the possibility of reef colonization and caused the complete drowning of the previous carbonate platform. The involved regression-transgression cycle with an amplitude on the order of 100 $\mathrm{m}$ (Fig. 9) during greenhouse time suggests a short-term cooling event during the late Maastrichtian (see Camoin et al., 1993). This time corresponds to a transitional period between two modes of oceanic circulation (e.g., equatorial to polar-dominated thermohaline circulation), inducing a sharp decrease in organic productivity (Camoin et al., 1993). In particular, a sharp decrease in sea-surface temperatures to about $21^{\circ} \mathrm{C}$ in the Pacific Ocean has been considered by Barrera et al. (1987). This time of moderately cool conditions began in the Maastrichtian and is thought to have continued, with fluctuations, into the late Paleocene when considerable warming occurred in bottom/polar water masses (see Camoin et al., 1993). A drastic collapse of carbonate platforms occurs in the latest part of the Maastrichtian throughout the Tethyan realm, mostly related to a regressive phase seemingly coinciding with the marked global eustatic fall recorded before the KTb (Camoin et al., 1993).

\section{Post-drowning Evolution}

Following the demise of the carbonate platform, subsidence (possibly combined with eustatic sea-level changes) rapidly carried the platform carbonates in a basinal setting below the aragonite saturation depth, resulting in the dissolution of aragonite and the subsequent in-place precipitation of calcite cements. Deep-marine waters that were responsible for these processes probably continuously invaded the carbonate cap of the guyot during its subsidence, especially through the very permeable sand facies constituting the bulk of the carbonate sequence. As dissolution processes in deep waters are much slower than in the meteoric environment, it seems likely that they lasted throughout the entire Cenozoic.

The first post-drowning sediments are late Paleocene in age. Considering an average rate of subsidence of $25 \mathrm{~m} / \mathrm{m}$.y. (Detrick and Crough, 1978), the guyot was probably between 250 and $300 \mathrm{~m}$ deep in the late Paleocene and entered the oxygen-minimum zone when the phosphatization started and, with the intensification and expansion of the oxygen-minimum zone, increased amounts of Mn and manganophile elements produced a manganese crust. These data are also consistent with the present-day aragonite saturation depth, which is $300-$ $400 \mathrm{~m}$ in the modern Pacific Ocean (Li et al., 1969; Scholle et al., 1983).

\section{CONCLUSIONS}

The shallow-water carbonate sequence of Wodejebato Guyot documents the submergence of a volcanic island, followed by the development and the demise of a Campanian-Maastrichtian carbonate platform or atoll-like structure.

The depositional history of the inner perimeter ridge of Wodejebato Guyot began with the end of volcanism, either before or during Campanian time, and the subsequent subaerial exposure that created a 15-m-thick weathering profile. 


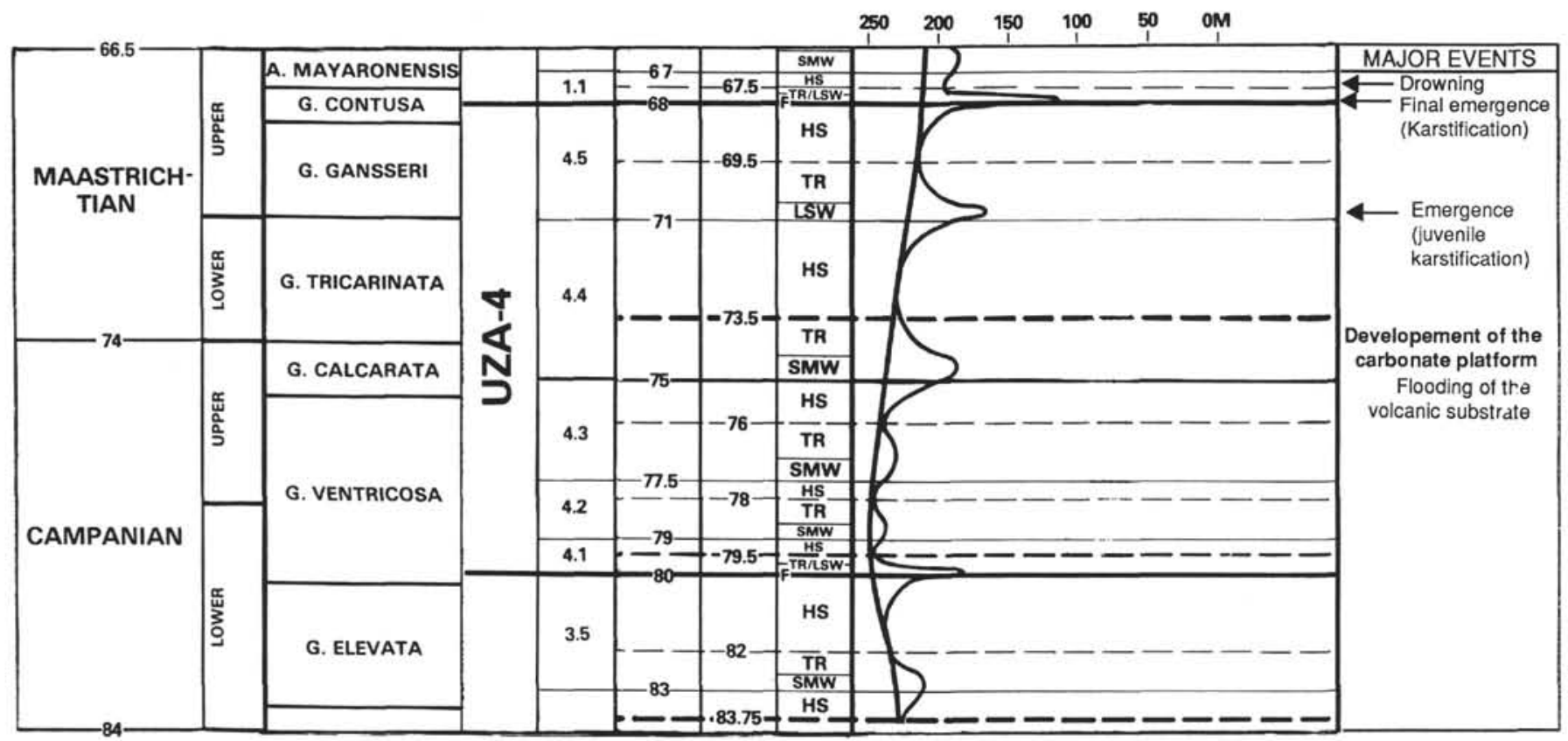

Figure 9. Correlations between Wodejebato Guyot depositional history (major events) and eustatic curve, supercycle, and systems tracts of Haq et al. (1987).

The initial marine deposits correspond to organic-rich clay deposited in a quiet, reducing, shallow-marine environment.

A two-stage transgression initiated the carbonate platform, leading to the accumulation of skeletal sand piles near the shelf margin, followed by the development of early cemented coralgal "reef" units that constituted barrier-like features. At that time, the carbonate platform was forming an atoll-like structure. The prolonged sea-level stand or the lowering of sea level may have induced local and temporary subaerial exposures in the last stages of platform development.

The morphology of the drowned atoll (hummocky upper surface of platform carbonates), the occurrence of a trough separating the inner perimeter ridge from the outer one, and the thorough penetration of platform carbonates by deep solution cavities suggest karstification processes before the final drowning of the carbonate platform during Maastrichtian time. The occurrence of Maastrichtian pelagic sediments as cavity fillings implies a rapid sea-level rise of a few tens of meters during late Maastrichtian time ( $G$. gansseri Zone), just after exposure. The complete shutdown of platform carbonate production during re-flooding was probably related to the combination of sealevel rise and deterioration of environmental conditions caused by strong but short climatic perturbations that characterize late Maastrichtian time.

Following the demise of the carbonate platform, subsidence possibly combined with eustatic sea-level changes to rapidly carry the platform carbonates in a basinal setting below the aragonite saturation depth, resulting in the dissolution of aragonite and the subsequent inplace precipitation of calcite cements, possibly throughout the Cenozoic. Post-drowning sediments correspond to a phosphate-manganese crust that formed from the late Paleocene to the middle Eocene when the guyot entered the oxygen-minimum zone.

\section{REFERENCES}

Al-Aasm, I.S., and Veizer, J., 1986. Diagenetic stabilization of aragonite and low-Mg Calcite, II. Stable isotopes in rudists. J. Sediment. Petrol., 56:763770 .

\footnotetext{
Abbreviations for names of organizations and publications in ODP reference lists follow the style given in Chemical Abstracts Service Source Index (published by American Chemical Society).
}

Anderson, T., and Schneidermann, N., 1973. Stable isotope relationships in pelagic limestones from the central Caribbean: Leg 15, Deep Sea Drilling Project. In Edgar, N.T., Saunders, J.B., et al., Init. Repts. DSDP, 15: Washington (U.S. Govt. Printing Office), 795-803.

Arnaud Vanneau, A., Camoin, G., et al., 1993. Les édifices carbonatés des atolls et guyots du Pacifique nord-occidental: résultats préliminaires du Leg ODP 144. C. R. Acad. Sci. Ser. 2, 317:947-954.

Barrera, E., Huber, B.T., Savin, S.M., and Webb, P.-N., 1987. Antarctic marine temperatures: late Campanian through early Paleocene. Paleoceanography, 2:21-47.

Bathurst, R., 1977. Ordovician Meiklejohn bioherm, Nevada. Geol. Mag., 114:308-311.

Baturin, G.N., 1971. Stages of phosphorite formation on the ocean floor. Nature Phys. Sci., 232:61-62.

Bergersen, D.D., 1993. Geology and geomorphology of Wodejebato (Sylvania) Guyot, Marshall Islands. In Pringle, M.S., Sager, W.W., Sliter, W.V., and Stein, S. (Eds.), The Mesozoic Pacific: Geology, Tectonics, and Volcanism. Geophys. Monogr., Am. Geophys. Union. 77:367-385.

Bourke, L., Delfiner, P., Fett., T., Grace, M., Luthi, S., Serra, O., and Standen, E., 1989. Using Formation MicroScanner images. Techn. Rev., 37:16-40.

Bourrouilh, F.G., 1979. Les plates-formes carbonatées de haute énergie à Rhodolites et la crise climatique du passage mio-pliocène dans le domaine pacifique. Bull. Cent. Rech. Expl.-Prod. Elf-Aquitaine, 3:489-495.

Burnett, W.C., Veeh, H.H., and Soutar, A., 1980. U-series, oceanographic and sedimentary evidences in support of Recent formation of phosphate nodules off Peru. In Bentor, Y.K. (Ed.), Marine Phosphorites: Geochemistry, Occurrence, Genesis. Spec. Publ. -Soc. Econ. Paleontol. Mineral., 29:61-71.

Camoin, G., Bellion, Y.J.C., Dercourt, J., Guiraud, R., Lucas, J., Poisson, A., Ricou, L.E., and Vrielynck, B., 1993. Late Maastrichtian (69.5-65 Ma). Explanatory notes. In Dercourt, J., Ricou, L.E., and Vrielynck, B. (Eds.), Atlas Tethys Paleoenvironmental Maps: Paris (Gauthier Villars), 179-196.

Camoin, G., Bernet-Rollande, M.-C., and Philip, J., 1988. Rudist-coral frameworks associated with submarine volcanism in the Maastrichtian strata from Pachino area (S.E. Sicily). Sedimentology, 35:128-143.

Chubb, L.J., 1971. Rudists of Jamaica. Paleontogr. Am., 45.

Collot, J.-Y., Greene, H.G., Stokking, L.B., et al., 1992. Proc. ODP, Init. Repts., 134: College Station, TX (Ocean Drilling Program).

Delamette, M., 1988. L'évolution du Domaine Helvétique de l'Aptien supérieur au Turonien. Publ. Dep. Geol. Paleontol. Univ. Geneve, 5.

Detrick, R.S., and Crough, S.T., 1978. Island subsidence, hot spots, and lithospheric thinning. J. Geophys. Res., 83:1236-1244.

Dominguez, L.L., Mullins, H.T., and Hine, A.C., 1988. Cat Island platform, Bahamas: an incipiently drowned Holocene carbonate shelf. Sedimentology, 35:805-819. 
Duennebier, F.K., and Petersen, L.K., 1982. Summary report, IPOD Site surveys in the western Pacific, R/V Kana Keoki cruise KK810626, Leg 4. Hawaii Inst. Geophys.

Emery, K.O., Tracey, J.I., Jr., and Ladd, H.S., 1954. Geology of Bikini and Nearby Atolls. Geol. Surv. Prof. Pap. U.S., 260-A.

Erlich, R.N., Barrett, S.E., and Guo, B.J., 1990. Seismic and geologic characteristics of drowning events on carbonate platforms. AAPG Bull., 74:650

Föllmi, K., 1989. Mid-Cretaceous platform drowning, current-induced condensation and phosphogenesis, and pelagic sedimentation along the Eastern Helvetic Shelf (Northern Tethys Margin). In Wiedmann, J. (Ed.), Cretaceous of the Western Tethys, 563-606.

Freeman-Lynde, R.P., Fulker Whitley, K., and Lohmann, K.C., 1986. Deepmarine origin of equant spar cements in Bahama Escarpment limestones. J. Sediment. Petrol., 56:799-811.

Gonzalez, L.A., and Lohmann, K.C., 1985. Carbon and oxygen isotopic composition of Holocene reef carbonates. Geology, 13:811-814.

Grötsch, J., and Flügel, E., 1992. Facies of sunken Early Cretaceous atoll reefs and their capping late Albian drowning succession (northwestern Pacific). Facies, 27:153-174.

Haggerty, J.S., 1982. Marine vs. fresh water diagenesis of Tertiary carbonates from Pacific seamounts in the Line Islands chain. Geol. Soc. Am. Abstr. Progr., 505.

Hamilton, E.L., and Rex, R.W., 1959. Lower Eocene phosphatized Globigerina ooze from Sylvania Guyot. Geol. Surv. Prof. Pap. U.S., 260-W:785797.

Haq, B.U., Hardenbol, J., and Vail, P.R., 1987. Chronology of fluctuating sea levels since the Triassic. Science, 235:1156-1167.

Harker, S.D., McGann, G.J., Bourke, L.T., and Adams, J.T., 1990. Methodology of Formation Micro Scanner image interpretation in Claymore and Scapa Fields (North Sea). In Hurst, A., Lovell, M.A., and Morton, A.C. (Eds.), Geological Applications of Wireline Logs. Geol. Soc. Spec. Publ. London, 48:11-25.

Hein, J.R., Bohrson, W.A., Schulz, M.S., Noble, M.A., and Clague, D.A., 1992. Variations in the fine-scale composition of a Central Pacific ferromanganese crust: paleoceanographic implications. Paleoceanography, 7:63-77.

Hennebert, M., and Lees, A., 1991. Environmental gradients in carbonate sediments and rocks detected by correspondence analysis: examples from the Recent of Norway and the Dinantian of southwest England. Sedimentology, 38:623-642.

Hine, A.C., and Steinmetz, J.C., 1984. Cay Sal Bank, Bahamas-a partially drowned carbonate platform. Mar. Geol., 59:153-164.

Jarvis, I., 1980. The initiation of phosphatic chalk sedimentation-the Senonian (Cretaceous) of the Anglo-Paris Basin. In Bentor, Y.K. (Ed.), Marine Phosphorites: Geochemistry, Occurrence, Genesis. Spec. Publ.Soc. Econ. Paleontol. Mineral., 29:167-192.

Kauffman, E.G., and Sohl, N.F., 1974. Structure and evolution of Antillean Cretaceous rudist frameworks. Verh. Naturforsch. Ges. Basel, 84:399467.

Kendall, A., 1977. Fascicular-optic calcite: a replacement of bundled acicular carbonate cements. J. Sediment. Petrol., 47:1056-1062.

Kendall, A.C., 1985. Radiaxial fibrous calcite: a reappraisal. In Schneidermann, N., and Harris, P.H. (Eds.), Carbonate Cements. Spec. Publ.-Soc. Econ. Paleontol. Mineral., 36:59-77.

Kroopnick, P.M., Margolis, S.V., and Wong, C.S., 1977. $\delta^{13} \mathrm{C}$ variations in marine carbonate sediments as indicators of the $\mathrm{CO}_{2}$ balance between the atmosphere and oceans. In Anderson, N.R., and Malahoff, A. (Eds.), The Fate of Fossil Fuel $\mathrm{CO}_{2}$ in the Oceans: New York (Plenum Press), 295-321.

Land, L.S., and Moore, C.H., 1980. Lithification, micritization and syndepositional diagenesis of biolithites on the Jamaican Island slope. J. Sediment. Petrol., 50:357-370.

Li, Y.-H., Takahashi, T., and Broecker, W.S., 1969. Degree of saturation of calcium carbonate in the oceans. J. Geophys. Res., 75:5507-5525.

Lincoln, J.M., 1990. Regional tectonic history and Cenozoic sea levels deduced from drowned carbonate banks and atoll stratigraphy in the Marshall Island, West Cental Pacific Ocean. [Ph.D. dissert.]. Northwestern Univ., Evanston, IL.
Lincoln, J.M., Pringle, M.S., and Premoli-Silva, I., 1993. Early and Late Cretaceous volcanism and reef-building in the Marshall Islands. In Pringle, M.S., Sager, W.W., Sliter, W.V., and Stein, S. (Eds.), The Mesozoic Pacific: Geology, Tectonics, and Volcanism. Geophys. Monogr., Am. Geophys. Union, 77:279-305.

Lincoln, J.M., and Schlanger, S.O., 1987. Miocene sea level falls related to the geological history of Midway Atoll. Geology, 15:454-457.

Lohmann, K., and Meyers, W., 1977. Microdolomite inclusions in cloudy prismatic calcites. J. Sediment. Petrol., 47:1078-1088.

McNutt, M.K., Winterer, E.L., Sager, W.W., Natland, J.H., and Ito, G., 1990. The Darwin Rise: a Cretaceous superswell? Geophys. Res. Lett., 17:11011104.

Moldovanyi, E.P., and Lohmann, K.C., 1984. Isotopic and petrographic record of phreatic diagenesis: Lower Cretaceous Sligo and Cupido Formations. J. Sediment. Petrol., 54:972-985.

Montaggioni, L.F., and Camoin, G.F., in press. Geology of Makatea Island (Tuamotu Archipelago, French Polynesia). In Vacher, L., and Quinn, T.M. (Eds.), Carbonate Islands: Amsterdam (Elsevier).

Premoli Silva, I., Haggerty, J., Rack, F., et al., Proc. ODP, Init. Repts., 144: College Station, TX (Ocean Drilling Program).

Rao, V.P., and Burnett, W.C., 1990. Phosphatic rocks and manganese crusts from seamounts in the EEZ of Kiribati and Tuvalu, Central Pacific Ocean. In Keating, B., and Bolton, B. (Eds.), Geology and Offshore Mineral Resources of the Central Pacific Basin. AAPG/Circum. Pac. Monogr. Ser., 15:285-296.

Rao, V.P., Lamboy, M., and Natarajan, R., 1992. Possible microbial origin of phosphorits on Error Seamount, northwestern Arabian Sea. Mar. Geol., 106:149-164.

Saller, A.H., 1986. Radiaxial calcite in lower Miocene strata, subsurface Enewetakc Atoll. J. Sediment. Petrol., 56:743-762.

Sandberg, P.A., 1985. Aragonite cements and their occurrence in ancient limestones. In Schneidermann, N., and Harris, P.H. (Eds.), Carbonate Cements. Spec. Publ.-Soc. Econ. Paleontol. Mineral., 36:33-57.

Sandberg, P.A., and Hudson, J.D., 1983. Aragonite relic preservation in Jurassic calcite-replaced bivalves. Sedimentology, 30:879-892.

Schlager, W., 1974. Preservation of cephalopod skeletons and carbonate dissolution on ancient Tethyan sea floor. Spec. Publ.-Int. Assoc. Sedimentol., 1:49-70.

, 1981. The paradox of drowned reefs and carbonate platforms. Geol. Soc. Am. Bull., 92:197-211.

Schlager, W., and James, N.P., 1978. Low-magnesian calcite limestones forming at the deep-sea floor, Tongue of the Ocean, Bahamas. Sedimentology, 25:675-702.

Schlanger, S.O., Campbell, J.F., and Jackson, M.W., 1987. Post-Eocene subsidence of the Marshall Islands recorded by drowned atolls on Harrie and Sylvania guyots. In Keating, B.H., Fryer, P., Batiza, R., and Boehlert, G.W. (Eds.), Seamounts, Islands, and Atolls. Geophys. Monogr., Am. Geophys. Union, 43:165-174

Scholle, P.A., Arthur, M.A., and Ekdale, A.A., 1983. Pelagic environments. In Scholle, P.A., Bebout, D.G., and Moore, C.H. (Eds.), Carbonate Depositional Environments. AAPG Mem., 33:620-691.

Skelton, P.W., 1979. Gregariousness and proto-cooperation in rudists (bivalvia). In Larwood, G., and Rosen, B.R. (Eds.), Biology and Systematics of Colonial Organisms. Spec. Publ. Syst. Assoc., 11:257-279.

Tebbutt, G.E., Conley, C.D., and Boyd, D.W., 1965. Lithogenesis of a carbonate rock fabric. Contrib. Geol., 4:1-13.

Williams, L.A., 1984. Subtidal stromatolites in Monterey Formation and other organic-rich rocks as suggested source contributors to petroleum formation. AAPG Bull., 68:1879-1893.

Winterer, E.L., and Metzler, C.V., 1984. Origin and subsidence of guyots in Mid-Pacific Mountains. J. Geophys. Res., 89:9969-9979.

Date of initial receipt: 4 February 1994

Date of acceptance: 15 September 1994

Ms 144SR-035 

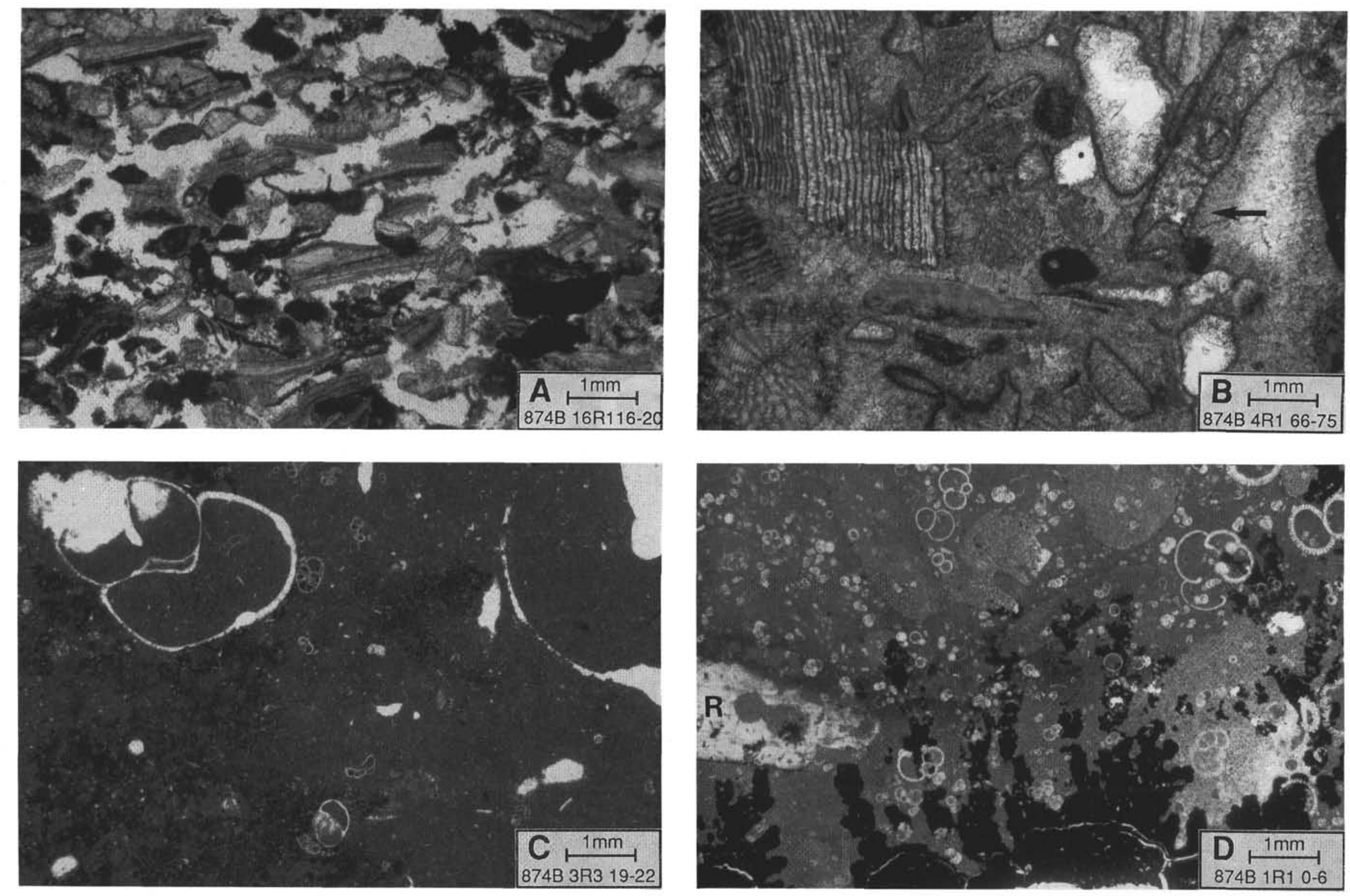

Plate 1. Thin-section photomicrographs. A. Porous skeletal grainstone typical of sand shoal facies. Skeletal grains primarily consist of fragments of rudists and red algae. B. Well-cemented skeletal grainstone with larger benthic foraminifers and rudists (radiolitids) fragments associated with the rudist-coralgal frameworks. Note the occurrence of thick, isopachous fringes of bladed to fibrous cements (arrow). C. Burrowed lagoonal wackestone with gastropods and small benthic foraminifers. D. Phosphate-manganese crust made of digitate and laminated accretions growing in pelagic sediments including reworked rudist fragments ("R"). 

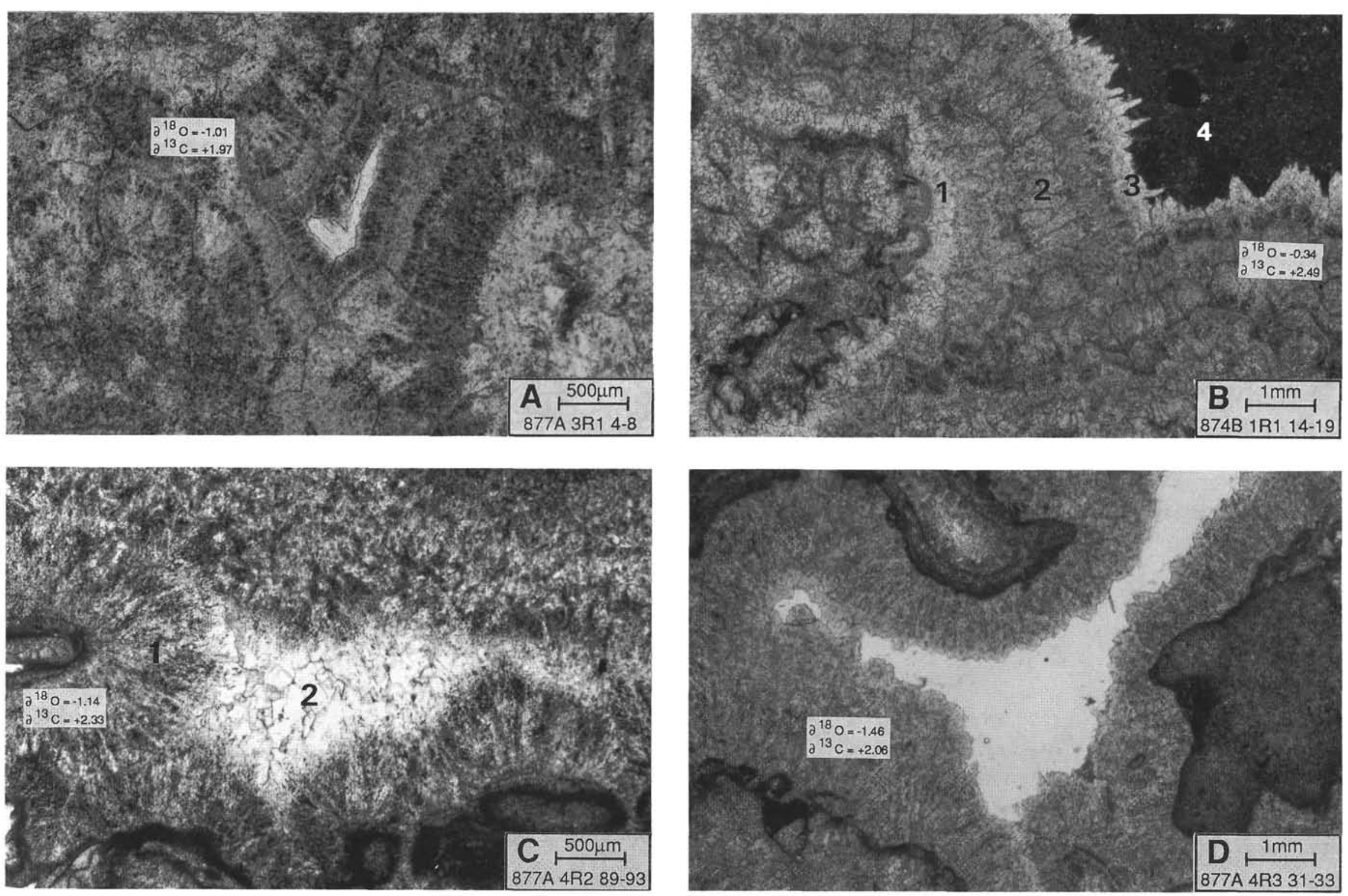

Plate 2. Thin-section photomicrographs of rudist-coralgal frameworks and associated skeletal grainstone and rudstone. Early cements consist of thick, isopachous fringes of radiaxial to fascicular-optic calcites with fibrous or bladed morphologies ( "2" on Plate 2B, and "1" on Plate 2C). These calcites appear to be zoned by variations of inclusion density with the outermost zone being generally clear and inclusion poor ("3" on Plate 2B). Note the occurrence of clear, granular calcite at the contact between grains and early calcite cements ("1" on Plate 2B). The remaining pore spaces are either empty (Plate 2D) or filled by clear, equant, blocky calcite cements or by internal micritic sediments ("4" on Plate 2B). 

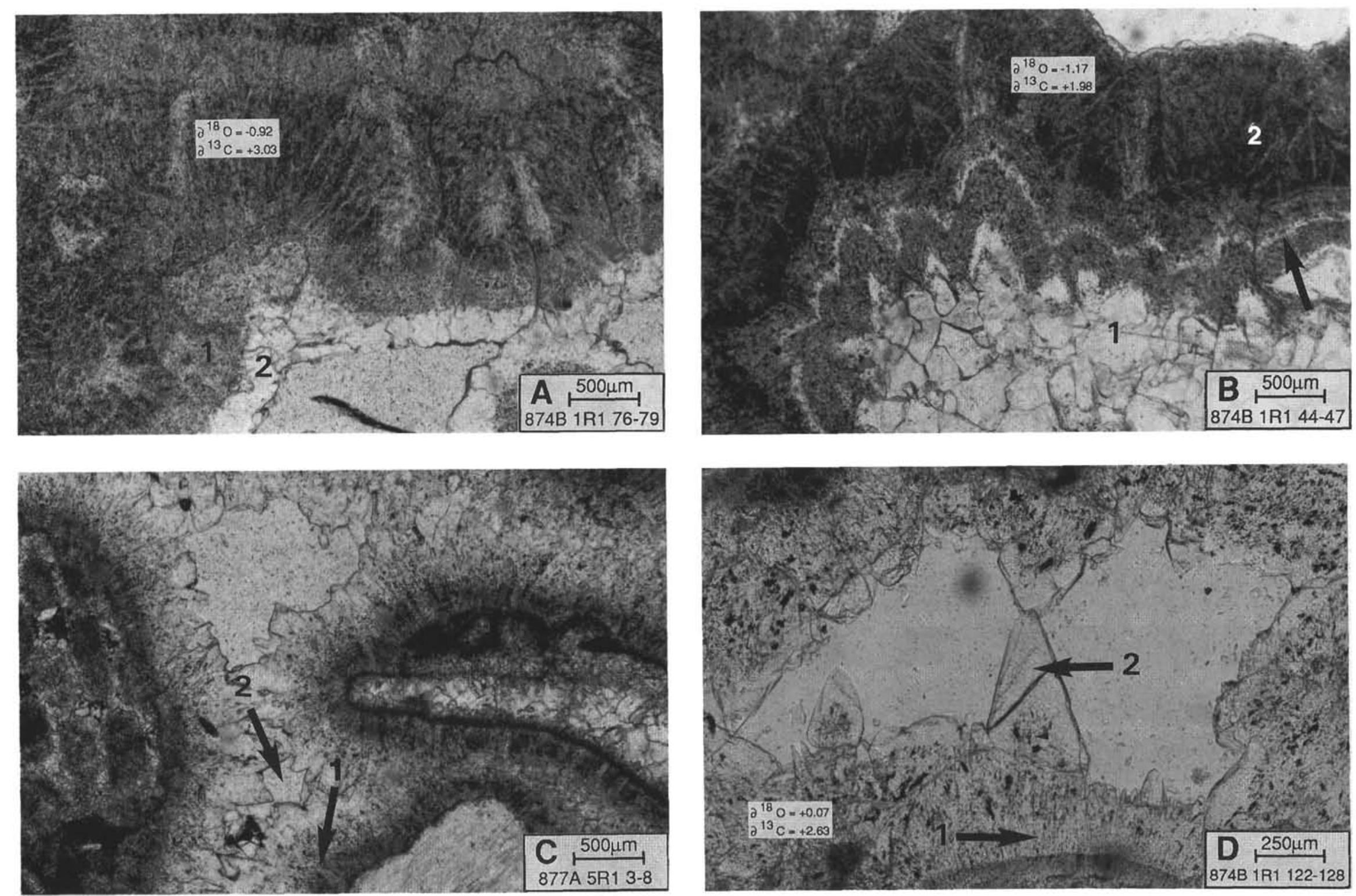

Plate 3. Thin-section photomicrographs of rudist-coralgal frameworks and associated skeletal grainstone and rudstone. A, B. Early cements consist of thick, isopachous fringes of radiaxial to fascicular-optic calcites which appear to be zoned by yariations of inclusion density with the outermost zone being generally clear, inclusion-poor ("2" on Plate 3A). Note the occurrence of clear, equant, blocky calcite cements ("1" on Plate 3B) and a thin fringe of granular calcite interlayered with bladed to fibrous calcites (arrow on B). C, D. Two-step cementation by isopachous fringes of bladed to fibrous cements (" 1 ") followed by clear, block to scalenohedral calcites ("2"). 

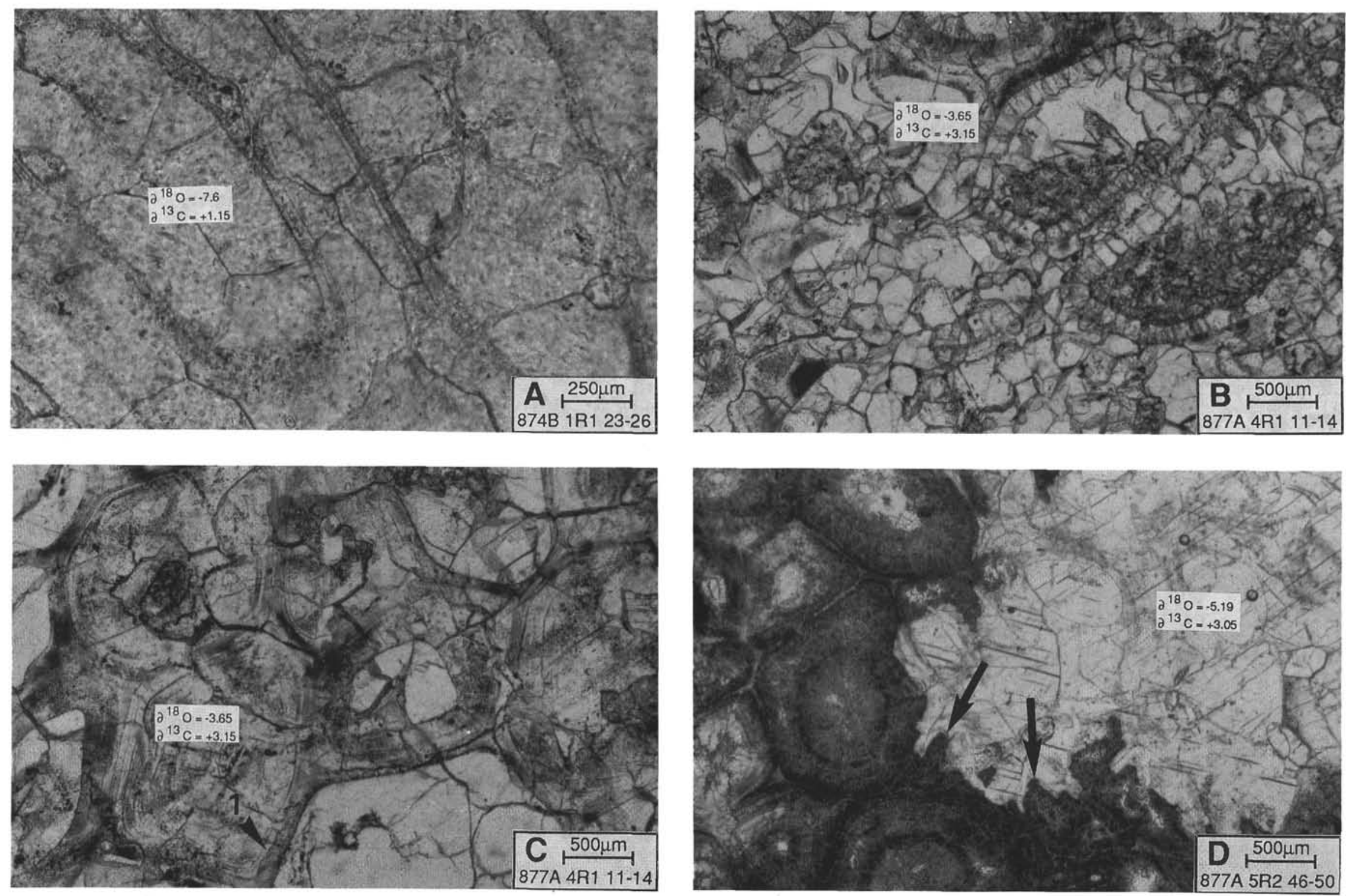

Plate 4. Thin-section photomicrographs showing diagenesis of rudists in the two "reef" unit. A, B. Complete transformation of rudist shells by clear, inclusion-free blocky calcites that display few relics of the former skeletal structure. C. Earlier step of transformation of a rudist shell where inclusion-poor blocky calcites cross cut the original aragonitic structures and associated calcite cements. D. Sharp and scalloped contact (arrows) between rather well-preserved aragonitic rudist shell and clear, blocky calcite cements that exhibit only few relics of the former skeletal structures. 